\title{
Inter-Enterprise Credit and Adjustment During Financial Crises: The Role of Firm Size *
}

\author{
Fabrizio Coricelli ${ }^{\dagger} \quad$ Marco Frigerio
}

June 2017

\begin{abstract}
SMEs suffered a sharp contraction in their borrowing from banks during the Great recession. Analyzing a large firm-level database for European countries, the paper shows that trade credit amplified the liquidity squeeze on SMEs. Because of their weaker bargaining power in the inter-enterprise credit market, SMEs sharply increased their net trade credit and thus transferred financial resources to larger firms. The paper finds that the liquidity squeeze induced by trade credit had large negative effects on real activity by SMEs, contributing to the fall in employment, wages and investments. Given the large weight of SMEs in the economy of European countries, the liquidity squeeze of SMEs likely contributed to the depth of the output fall and the slow recovery in Europe during the Great recession.
\end{abstract}

Keywords: trade credit, financial crises, SMEs

*The authors gratefully acknowledge the CEPR/Assonime Programme on Restarting European Long Term Investment Finance (RELTIF) for financial support. The authors are grateful to Vasso Ioannidou and Andrew Ellul for helpful remarks and suggestions on early versions. We also thank participants of RELTIF Authors' Meetings held in Milan (January 2016) and in Capri (July 2016) for their insightful comments.

${ }^{\dagger}$ F. Coricelli (Corresponding author), Paris School of Economics and CEPR

${ }^{\ddagger}$ M. Frigerio, University of Milan (DEMM) 


\section{Introduction}

The asymmetric impact of monetary policy across firms of different size has been a central theme in the so-called credit channel explaining contractionary effects of monetary tightening (Gertler and Gilchrist, 1994). Small and medium size firms (SMEs) face tighter credit constraints as they are unable to replace bank credit with alternative sources of financing, such as corporate bonds. Such asymmetric effects are likely to have been stronger during the Great Recession, as it has been the most severe financial crisis at the global level since the Great Depression. Therefore, it is worth asking whether SMEs suffered more than large firms during this episode and whether such asymmetric effect may account for the sharp output fall and the slow recovery during the Great recession, especially in Europe. The issue is particularly relevant in Europe because SMEs account for a large share of employment and value added in European countries. However, rather than on the role of frictions in bank credit for the heterogeneous transmission of the financial shock across different size classes, in this paper we focus on the role of frictions in trade credit. In this respect, one of the main frictions is likely to be the different bargaining power across firms of different size.

The macroeconomic dimension of trade credit and its connection with monetary/credit policy has been central to the monetary analysis in early post-War II period. For instance, in the influential Radcliffe Report (1959), which established the limits to monetary policy due to instability of money demand, trade credit played a central role as a way for firms to bypass the effects of monetary contractions. Such a theme was emphasized as well by Brechling and Lipsey (1963), Meltzer (1960) and Schwartz (1974). More recently, several contributions revived the interest on the macroeconomic dimension of trade credit. Ramey (1992) analyzed the relationship between money and trade credit in the US, while Kiyotaki and Moore (2001) stressed the role of trade credit chains in the magnification of idiosyncratic shocks. Raddatz (2010) provided empirical evidence on contagion effects of local shocks through trade credit chains. Furthermore, Love, Preve and Sarria-Allende (2007) and Love and Zaidi (2010) studied the behavior of trade credit during financial crises in 1990s in Asia and Mexico.

Following the macroeconomic approach, we focus on the liquidity transmission channel of trade credit and on the potential asymmetric behavior of trade credit across firms. During a phase of contraction in the supply of bank credit, trade credit may either provide a buffer or magnify the contraction in bank credit. Given our focus on firms heterogeneity and on the asymmetric effects of trade credit during the financial crisis, it is natural to focus on net trade credit, the dif- 
ference between receivables and payables. Indeed, given that firms are generally both suppliers and customers in the supply chain and thus both lenders and borrowers in the credit chain, the liquidity effect acts through net trade credit. In fact, in normal times, net trade credit positions are not very large and the credit chain appears rather circular. Kalemli-Ozcan et al. (2014) have emphasized the strong correlation at the firm level between payables and receivables and Calvo and Coricelli (1996) highlighted the high degree of circularity of inter-enterprise credit in transition countries. We do not underestimate the importance of gross trade credit (receivables and payables) for the real equilibrium of a system. In fact, our focus on net credit is justified by our objective of detecting a transfer of liquidity from a group of firms, SMEs, to another, large firms, during financial crises. Therefore, our focus is on firms heterogeneity and on liquidity transfers across firms, rather than contagion effects through gross trade credit positions within production chains. In summary, our contribution is totally complementary to the analysis of gross trade credit and its impact on credit and production chains.

The importance of firm size has been emphasized in the analyses of trade credit. In particular, in the early literature there was a consensus on the redistribution of liquidity through trade credit from large to small firms (Radcliffe Report, 1959; Meltzer, 1960; Schwartz, 1974). The explanation rests on the idea that large firms are better endowed with liquid assets and, moreover, they have easier access to bank financing. However, in the empirical literature, the evidence on whether SMEs tend to be net recipients of trade credit has been mixed. ${ }^{1}$ One aspect missing in the early literature is that SMEs may be overly represented as suppliers of inputs for larger firms. Therefore, for purely technological reasons, SMEs may be net suppliers of trade credit. The empirical analysis of determinants of net trade credit should thus disentangle the technological from the liquidity effects. In this paper, we tackle this issue by using the notion of upstreamness of production, namely the relative position of firms' production in the different stages of supply chains (Antras et al., 2012). Furthermore, in addition to firms' characteristics in terms of financial conditions and on the degree of upstreamness of their production, a key determinant of net trade credit is the relative bargaining power of firms in their credit relationship. Indeed, it is likely that large firms have stronger bilateral bargaining power with respect to SMEs, as large firms can more easily substitute their suppliers than SMEs can substitute one of their large customers. In our empirical analysis, we try to shed light on this aspect by using information

\footnotetext{
${ }^{1}$ Economic historians noted that SMEs may actually be net lender in the trade credit market (Thomas, 1978).
} 
from the input-output tables.

Closest to our work are the contributions by Love, Preve and Sarria-Allende (2007) and Love and Zaidi (2010), who investigate the behavior of trade credit during financial crises in Asia and Mexico during the 1990s. Their work is mainly aimed at showing that trade credit does not provide a buffer to the credit shock coming from the contraction of bank credit, typical of financial crises. Their focus is on gross trade credit, rather than net trade credit and the two papers concentrate one on large firms and the other on small and medium size firms.

We extend the previous literature on the role of trade credit during financial crises in four main directions. First, we focus on net trade credit as measure of liquidity pressure on firms, in line with early work by Meltzer (1960). Second, in relation to the potential asymmetric effects on SMEs, we introduce a novel approach to estimate differential bargaining power of SMEs, by using input-output tables to identify the average size of customer-suppliers. Third, we apply Angrist and Pischke (2008) two-stage approach to isolate the firm level, the industry level and country level determinants. Such two-stage approach allows us to tackle endogeneity problems and, at the same time, it allows us to properly identify industry and country level effects. Finally, we quantify the effects of net trade credit on firms' performance during the financial crisis, focusing on wage/employment changes and on investments.

Our main result is that during the Great Recession, European SMEs have been adversely affected by a sharp increase in net trade credit, which induced a squeeze in their liquidity. This phenomenon did not characterize large firms. Our econometric analysis shows that weaker bargaining power by SMEs in their inter-enterprise relationship contributes to explaining the asymmetric effect. Such effect varies as well depending on firms' characteristics, as more liquid SMEs are in a better position to provide trade credit to their customers. However, this may lead to a highly inefficient outcome, as better firms are those that suffer the larger liquidity shock through the trade credit market. In turn, the liquidity squeeze has a significant negative impact on wages and employment, as well as on investments, thus inducing long-term negative effects on SMEs' growth.

The paper is structured as follows. Section 2 briefly reviews the related literature. Section 3 contains our empirical analysis on determinants of the change in net trade credit during the Great Recession in Europe. Section 4 examines the potentially negative impact of net trade credit on investments and employment. Section 5 concludes. Robustness checks on the main regressions and the industry-level indicators of upstreamness and the average relative size of firms from input-output tables are contained in the Appendix. 


\section{The liquidity channel of trade credit: A brief overview of the literature}

Trade credit theories can be divided in two types, one focusing on net trade credit and the other on gross trade credit. The net trade credit literature emphasizes the redistribution of liquidity through the trade credit channel. Liquidity-rich firms support liquidity-poor firms by extending trade credit during periods of tightening of financial constraints. This approach dominated the literature until the end of 1970s. Meltzer (1960), Brechling and Lipsey (1963), Schwartz (1974), in addition to the Radcliffe Report (1959) are examples of the early literature.

Theories based on gross trade credit have been pioneered by Ferris (1981), who emphasized the transaction cost channel of trade credit. According to Ferris (1981), firms facing an uncertain timing of delivery of goods can economize in cash inventories by relying on trade credit. As firms are typically both customers and suppliers in inter-enterprise transactions, irrespective of net trade credit positions, they can minimize their cash holdings by allowing inter-enterprise transactions to be effected through trade credit. Without trade credit, firms would have to hold large amounts of cash (or liquid assets) in order to effect their transactions. Therefore, for the enterprise sector as a whole, trade credit permits economizing on cash holdings. The higher the degree of circularity of the system (the closer, for each firm, is the value of purchases and sales to other firms), the closer net debt positions are to zero. Kalemli-Ozcan et al. (2014) develop a theory and provide empirical evidence on the importance of gross trade credit flows, by showing a high degree of correlation between payables and receivables at the firm level. Kim and Shin (2012) develop a theory of gross trade credit based on moral hazard in production chains. In activities that are not fully vertically integrated, trade credit provides a commitment to higher effort by firms involved in the production chain. As the expected returns to activities by each producer in the chain depend on the success in selling the final product at the end of the chain, trade credit creates incentives for all input producers to provide effort in order to ensure the success of the whole production chain. Interestingly, from such a model receivables are a function of payables and of sales of each firm. Furthermore, the model implies a Cobb-Douglas relationship between receivables on one side and payables and sales on the other, which ensures constant returns to scale in trade receivables. The important insight in this approach is that microeconomic theories of corporate finance trying to explain trade debt or trade credit are not very relevant, as each firm is both debtor and creditor in the production chain. Whether, on 
net, a firms ends up being a creditor or debtor depends mainly by its position in the production chain. Kim and Shin theory is thus an equilibrium theory of trade receivables for an entire sector or country. Nevertheless, their theory implies that firms with different relative size are going to be characterized by different levels of net trade credit. Specifically, if a customer firm is large relative to its supplier, she is going to be a net creditor and in explaining her receivables sales will have a larger weight relative to payables. A relevant question is whether trade credit as a commitment device plays the same role in "normal" times and in financial crises. Conceivably, financial crises induce a sharp increase in uncertainty on the fate of the whole production chain, thus weakening the scope for trade credit as a commitment device.

Kiyotaki and Moore (2001) develop a theory of credit chains that encompasses both the gross and net trade theories. Indeed, in their model liquidity is transferred from liquidity-rich to liquidity-poor firms, but this occurs through a potentially long chain, which serves as contagion channel for localized shocks.

What happens during financial crises? Several studies analyzed the behavior of trade credit during financial crises, focusing on the relationship between bank and trade credit. Norden and van Kampen (2015) find that the substitutability between bank debt and trade credit tends to weaken during crises. As a result, trade credit behaves procyclically, thus amplifying the output fall during recessions. Nilsen (2002) argues that trade credit can help to redistribute resources from healthy to vulnerable firms, thus alleviating the negative effects of monetary contractions. ${ }^{2}$ By contrast, Raddatz (2010) argues that during financial crises, rather than redistributing resources, trade credit is a source of contagion of financial shocks through the production chain, giving rise to a significant amplification mechanism. ${ }^{3}$

Therefore, liquidity effects of trade credit, in particular during financial crises, operate through two distinct channels.

The first channel, the contagion channel, may induce an evaporation of liquidity and thus determine a potential break-up of production chains, with a consequent output collapse. ${ }^{4}$

The second channel, the redistribution channel, may work in an ambiguous way during financial crises. One possibility is that liquidity-rich firms transfer resources to liquidity poor firms, thus alleviating the adverse effects of contraction

\footnotetext{
${ }^{2}$ See also Biais and Gollier (1997).

${ }^{3}$ See also Boissay and Gropp (2013).

${ }^{4}$ For instance, this effect has been noted during the Great Recession in connection with the collapse of international trade (Mora and Powers, 2009).
} 
in bank credit. In this case, we would talk about a substitution effect between bank and trade credit. By contrast, trade credit can collapse as a result of the crunch in bank credit. This complementarity effect is consistent with the fact that in normal times commercial banks are likely to play de facto the role of lender of last resort for the trade credit market, as firms can access bank loans to absorb payments problems affecting individual firms. During a financial crisis banks are unlikely to play such role of lender of last resort, as they are the source of the financial shock (Coricelli and Frigerio, 2015).

In sum, the contagion channel can be seen as a link between production and credit chains. In normal times, the availability of trade credit may increase the division of labor by inducing a finer specialization in the production of intermediate goods through the production chain. Trade credit may thus play an important role in supporting more efficient resource allocation in normal times. However, the longer a production chain is, the higher is the exposure of the system to a potential collapse induced by an interruption of credit flows. This effect works irrespective of net credit positions and it works even in an environment of homogeneous firms. By contrast, the redistribution channel implies heterogeneity among firms. In this case, trade credit strongly depends on firm-level characteristics, some of which are undoubtedly related to firm size. Berger and Udell (1998), for example, show that trade credit is an essential source of financing for firms at an early stage of development, which are typically SMEs. Moreover, Giannetti, Burkart and Ellingsen (2011) find that suppliers provide more credit to customers with a higher market power, which is in turn related to firm size. Therefore, our focus on trade credit intersects with the broader theme of SMEs' dependence on external financing and thus the exposure of SMEs to financial shocks (see RELTIF Green Paper ${ }^{5}$ ).

\subsection{Trade credit and SMEs during financial crises}

The behavior of SMEs in the trade credit market during financial crises has also been analyzed in the literature. ${ }^{6}$

\footnotetext{
${ }^{5}$ Giovannini et al. (2015).

${ }^{6}$ Carbo-Valverde, Rodriguez-Fernandez and Udell (2013) find that during the last financial crisis the capital expenditure of credit-constrained Spanish SMEs was increasingly funded with trade credit. However, the potentially higher importance of trade credit for the external financing of SMEs contrasts with the fact that large firms are generally in a better position than SMEs to negotiate the terms of payment of inter-enterprise credit and of credit to final customers (households and the public sector).
} 
Since trade credit often involves firms that are tied by long-term relationships, suppliers are usually keen to provide trade credit to their customers in order to deal with potential sunk costs (Cunat, 2007). Therefore, when a relevant productmarket relationship exists, trade creditors may be even more interested than banks to provide credit to troubled customers (Wilner, 2000). SMEs may lose important clients if they impose shorter payment periods. This may paradoxically lead SMEs to extend (and accept) terms of payment that are more favorable to large firms, in spite of the fact that their access to bank credit is already more constrained.

Love and Zaidi (2010) study the behavior of trade credit of SMEs in the context of the Asian financial crisis in the 1990s. During this episode, vulnerable and credit-constrained companies tend to reduce their supply of trade credit. However, vulnerable small and medium private firms are also unable to increase their reliance on trade credit (i.e. payables), either because their suppliers are in turn financially constrained or because they are not willing to assist firms that are financially constrained, especially if these customers have weak market power. ${ }^{7}$ This result contrasts with those obtained in Love, Preve and Sarria-Allende (2007) for a sample of large firms during the Asian and Mexican crises of the 1990s, in which they find that large and publicly traded firms manage to obtain a relatively higher amount of trade credit from suppliers in the aftermath of the crisis.

In this paper, focusing on Europe, we investigate whether the liquidity redistribution from SMEs to large firms has a more general application, and specifically whether it has been at work during the Great Recession. Accordingly, this paper analyzes the positioning of European SMEs with respect to trade credit and discusses the changes brought about by the global financial crisis.

\section{Trade Credit and the financial crisis: Empirical analysis}

Using a large firm-level dataset, we try to understand whether during (and in the aftermath of) the Great Recession, trade credit constitutes a relevant alternative source of financing for SMEs, or whether it contributes to drain available resources from their balance sheets to the benefit of large companies.

\footnotetext{
${ }^{7}$ See also Brennan, Maksimovics and Zechner (1988).
} 


\subsection{Data sample}

Our analysis is carried out at the firm level using the Bureau Van Dijk Amadeus database. Firm-level data allow to take into account heterogeneity among firms and specific firm characteristics (such as size, age, financial health, profitability), which cannot be evaluated when analyzing macro-aggregated data. We developed a well-defined procedure in order to prepare and clean up data obtained from the database. First, in Amadeus there are many firm-year observations where the value of accounts payables and/or receivables is equal to zero. In our research we embrace the well-founded opinion that in many cases the zeros include missing or unknown information on trade credit. As a consequence, we only consider firms with positive values of account payables and account receivables.

Furthermore, data quality controls were used to drop firms with missing or unreliable data for all the variables of interest and outliers for some financial ratios. In particular, the values of variables of interest below the first percentile and above the 99th percentile were discarded.

Finally, firm-year observations are included in our final sample only on the condition that they are available for at least two consecutive years, in order to guarantee their reliability and the existence of lagged data for the regressions.

As a result of this cleaning procedure, our final sample includes nearly 2 million firms and 8 million firm-year observations. The panel is unbalanced and the observations cover a period of ten years from 2004 to 2013. Firms in the sample are located in 31 European countries, although data coverage varies across countries. About 60 percent of the observations are related to firms located in France, Italy and Spain, whereas 15 percent are located in Central-Eastern Europe. SMEs represent 98 percent of the total sample. The size classes are determined using information on the number of employees (when recorded) and turnover. The classification is based on the size classes defined by the European Commission. ${ }^{8}$

The empirical analysis requires a sufficiently detailed industry classification of the firms included in the sample. In particular, we subdivide firms by NACE Rev. 2 codes at the three-digit level, after excluding firms without an available code. Furthermore, we exclude industries that are outside the non-financial business economy: agriculture, forestry and fishing (section A of NACE Rev.2), financial and insurance activities (section K), public administration, education, health,

\footnotetext{
${ }^{8}$ Micro enterprises employ fewer than 10 workers and have an annual turnover not exceeding 2 million euro. 50 workers and a turnover of less than 10 million euro are the corresponding ceilings for small firms. For medium-sized enterprises, the cut-off points are 250 workers and a turnover of less than 50 million euro. The remaining firms are classified as large.
} 
entertainment (sections from $\mathrm{O}$ to $\mathrm{R}$ ) and other service activities (section $\mathrm{S}$ with the exception of division S95, repair of computers and personal and household goods). Following Klapper, Laeven and Rajan (2006), we also exclude mining and quarrying (section B) and utilities (sections D and E), which include highly regulated and state-owned firms. As a consequence of these exclusions, the final dataset is comprehensive of 199 NACE industries at the three-digit level. Most firms are almost equally distributed within the following activities: manufacturing (17.2 percent), construction (16.9 percent), wholesale trade (14 percent), retail trade (15.4 percent) and business services (14.6 percent). The remaining observations are in real estate activities (7.4 percent), transport and communication (8.9 percent), accommodation and food services (5.5 percent).

\subsection{Net trade credit and firms' characteristics}

Our main variable of interest at the firm level is the Net Trade Credit to Sales ratio, $N T C S$, with such ratio multiplied by 360 so that it can be expressed in terms of days, as a duration indicator. Negative (positive) values of net trade credit identify those firms that are net borrowers (lenders) with respect to trade credit.

Fig. 1 shows that, throughout the sample period, the median level of NTCS increases from 11.4 days in 2004 to about 18 days in the aftermath of the financial crisis, i.e. the period 2010-2013. Therefore, with the crisis approaching its peak the exposure of the median firm to the rest of the system in terms of trade credit increases and, in later years, it remains at levels that are higher than those prevailing in pre-crisis years. In addition, heterogeneity is very high around the median values and it reaches its maximum levels in 2012, when the difference between the 75 th percentile and the 25 th percentile is equal to 75.8 days.

Fig. 2 provides data on NTCS of non-financial corporations broken down by macro-regions, age, size and industry group. These are time-invariant or slowly changing factors that can influence the levels of net trade credit across firms.

When differentiating by country groups (chart A), median values not only depend on specific country characteristics but also on the distribution of firms in each country. Looking at median values, net trade credit ratio tends to be higher in South-Western Europe and lower in Eastern Europe, with North-Western Europe lying in the middle.

Interestingly, net trade credit in our final sample shows a non-linear relationship with respect to firm size (chart B). Median levels of net trade credit are higher for small and medium enterprises (respectively 20.5 and 19.9 days) and lower for micro and large enterprises (respectively 14.5 and 16.2 days). However, hetero- 
Figure 1: Net Trade Credit to Sales by Year

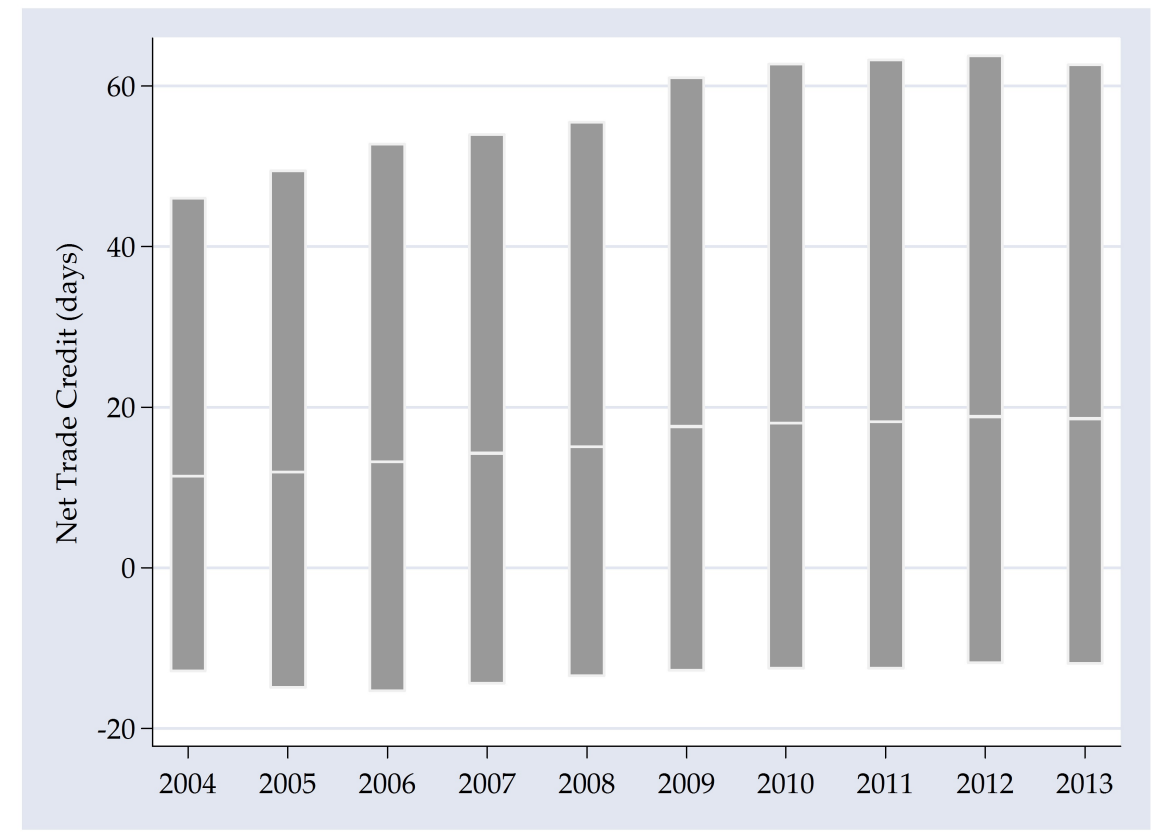

Inter-quintile range and median level of NTCS by year.

geneity within each class decreases with size and the more indebted firms (i.e. the lowest 25 th percentiles, as positive net trade credit indicates a lending position) belong to the micro and small size classes.

Net trade credit also increases with the age of companies (chart C). Median values range from 10.3 day for youngest firms (first quintile by age corresponding to firms less than 6 years old) to 22.7 for oldest firms (fifth quintile by age corresponding to firms more than 23 years old). Consistently with Berger and Udell (1998), young firms face larger obstacles to borrowing funds from external sources and thus they are more likely to borrow from more established suppliers, while being more reluctant to lend to their customers.

Finally, the impact of trade credit on the balance sheet of a firm is strongly influenced by technological characteristics. As shown in Fig. 2, the median value of net trade credit is negative in Retail Trade and in Accommodation and Food Services (respectively -12.4 and -10.4 days), revealing that most of the enterprises within these industry groups are net borrowers in terms of trade credit. By contrast, Business services and Transport and Communication are the industry groups 
Figure 2: Net Trade Credit to Sales by Year

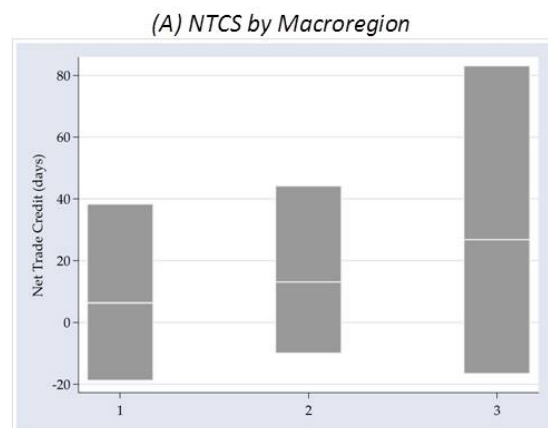

Macroregions: (1) Central and Eastern Europe; (2) NorthWestern Europe; (3) South-Eastern Europe.

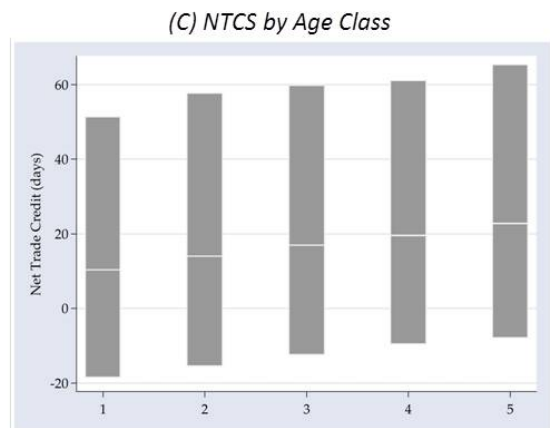

Age Classes: (1) Less than 6 years; (2) Between 7 and 10 years; (3) Between 11 and 16 years; (4) Between 17 and 23 years; (5) More than 23 years.
(B) NTCS by Size Class

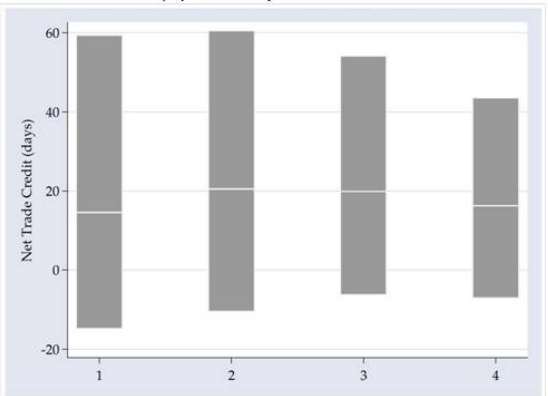

Size Classes: (1) Micro; (2) Small; (3) Medium; (4) Large.

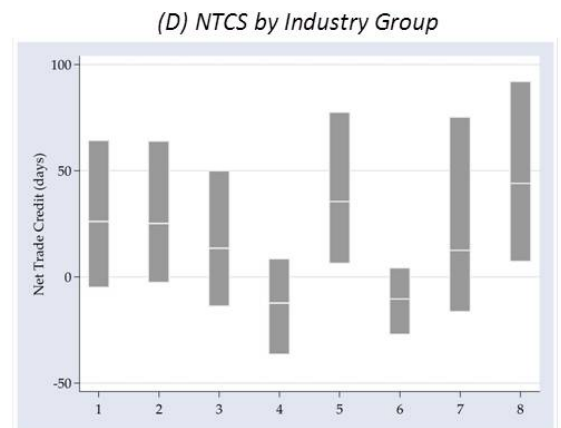

Industry Group: (1) Manufacturing; (2) Construction; (3) Wholesale trade; (4) Retail trade; (5) Transport and communication; (6) Accommodation and food services; (7) Real estate; (8) Business services.

Inter-quintile range and median level of NTCS by cluster.

with the highest positive values of net trade credit (44.1 and 35.5 days).

We next examine heterogeneity across industries by analyzing NTCS at the three-digit level industry classification. To emphasize structural characteristics, we first focus on pre-crisis values of NTCS for all the 199 industries within our sample. First, following the procedure applied in Raddatz (2010), ${ }^{9}$ we obtain a representative measure of NTCS for each firm in the sample by taking the firmlevel median across the pre-crisis period 2004-2007. Then, the median of these

\footnotetext{
${ }^{9}$ Raddatz (2010) measures the relative use of trade credit across US manufacturing industries through two main ratios: the relative payables financing and the relative short-term debt to payables.
} 
representative measures is taken within each three-digit NACE industry in order to define the representative pre-crisis ratios for each industry in Europe. These representative ratios are presented in Appendix B.1 (Table 16). Pre-crisis NTCS ranges from -31.5 days in Retail Sale of Cultural and Recreation Goods in Specialized Stores to 68.1 days in Accounting, Bookkeeping and Auditing Activities; Tax Consultancy.

This ranking seems to be influenced by the relative position in the production chain of each industry. Such relative position can be measured in relation to the degree of upstreamness of each sector. Upstreamness is defined as the average distance of any individual industry from final-good production. Antras et al. (2012) construct their measure of upstreamness using the US benchmark Input-Output (I-O) Tables from Bureau of Economic Analysis (BEA), which comprises 426 industries. We use their measure, under the assumption that upstreamness is a rather stable characteristic of industries across different countries. ${ }^{10}$ After reclassifying US industries in accordance to the NACE Rev. 2 definitions, we apply the original procedure of Antras et al. (2012) to the reclassified industries in order to derive the upstreamness variable. ${ }^{11}$

The values of upstreamness across NACE industries are listed in Appendix B.2 (Table 17). They range from a minimum of 1.007 for the Manufacture of Motor Vehicles to a maximum of 3.537 for the Manufacture of Refractory Products. By construction, these values can be interpreted as the number of production stages that separate a given industry from final costumers. ${ }^{12}$

Fig. 3 suggests a positive correlation between upstreamness and pre-crisis levels of NTCS (the correlation coefficient is 0.44 ). The net trade credit ratio is higher among those suppliers (upstream industries) that are more distant from the final customers. By contrast, net borrowers (negative values of NTCS) are concentrated among those (downstream) industries that are closer to the final customers. ${ }^{13}$ On

\footnotetext{
${ }^{10}$ Moreover, using European I-O tables, which are much less disaggregated, would have implied focusing on a much smaller, and thus more aggregated, set of sectors.

${ }^{11}$ The concordance between US industries in the US benchmark I-O Tables and industries in the NACE Rev. 2 classification is not perfect. The reclassification requires some minimal approximation and the aggregation within subgroups of NACE industries. Consequently, we finally obtain only 111 distinct values of upstreamness versus 199 NACE industries at three-digit level. So, some NACE industries in our ranking share the same level of upstreamness.

${ }^{12}$ Motor vehicles directly go to final customers while refractory products enter into use in production processes roughly 2.5 stages before final use.

${ }^{13}$ According to Kalemli-Ozcan et al. (2014), this result can be explained by referring to incentive compatibility constraints. In the production chain, the upstream firms are further away from their customers, and thus from the effects of their actions (low or high effort). As a result, they have
} 
Figure 3: Upstreamness and pre-crisis NTCS by Industry

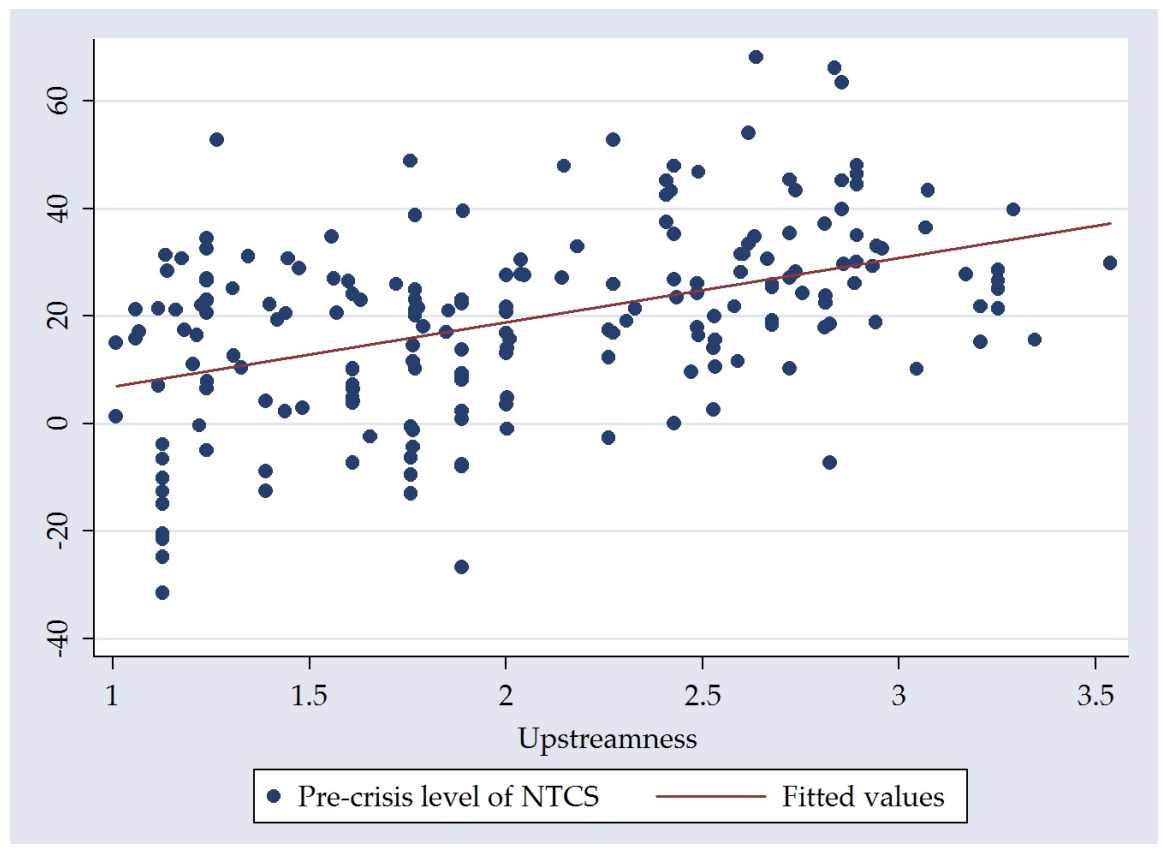

average, NTCS increases by 11-12 days for each additional stage of distance from final customers.

Moving to firm-level characteristics, Table 1 presents descriptive statistics on the relevant firm-level ratios. Cash is the ratio of cash and cash equivalent over total assets, assumed to be a good proxy of firms' liquidity. Tangibility is the ratio of tangible fixed assets over total assets. Leverage is the sum of long-term debt and loans divided by total assets. ShortLev is a possible alternative of the Leverage measure, considering only loans rather than the sum of long-term debt and loans, i.e. the short term. Finally, Profitability is operating profit over total assets, whereas $C f w$ is cash flow to total assets. Cash flow is obtained as the sum of profit (loss) for the period and depreciation.

lower incentives for effort. Trade credit can provide the right incentives for higher effort, as the return to upstream firms depends on the efficient working of the whole chain. 
Table 1: Summary Statistics (averages over 2004-2013)

\begin{tabular}{|c|c|c|c|c|c|c|}
\hline \multicolumn{7}{|c|}{ SMEs } \\
\hline Variable & Obs. & Mean & p25 & Median & p75 & St.Dev. \\
\hline \multicolumn{7}{|l|}{ Dep. Variable: } \\
\hline NTCS & $7,694,813$ & 28.28 & -13.19 & 16.48 & 59.24 & 97.31 \\
\hline \multicolumn{7}{|l|}{ Control Variables: } \\
\hline Cash & $7,697,052$ & 0.16 & 0.02 & 0.09 & 0.25 & 0.19 \\
\hline Tangibility & $7,773,541$ & 0.21 & 0.04 & 0.12 & 0.31 & 0.23 \\
\hline Leverage & $7,770,109$ & 0.15 & 0.00 & 0.06 & 0.26 & 0.19 \\
\hline ShortLev & $7,768,375$ & 0.06 & 0.00 & 0.00 & 0.08 & 0.11 \\
\hline Profitability & $7,693,875$ & 0.08 & 0.01 & 0.05 & 0.13 & 0.13 \\
\hline $\mathrm{Cfw}$ & $7,694,884$ & 0.09 & 0.03 & 0.07 & 0.14 & 0.11 \\
\hline \multicolumn{7}{|c|}{ Large companies } \\
\hline Variable & Obs. & Mean & $\mathrm{p} 25$ & Median & p75 & St.Dev. \\
\hline \multicolumn{7}{|l|}{ Dep. Variable: } \\
\hline NTCS & 155,276 & 21.86 & -7.10 & 16.23 & 43.60 & 64.03 \\
\hline \multicolumn{7}{|l|}{ Control Variables: } \\
\hline Cash & 152,843 & 0.08 & 0.01 & 0.04 & 0.10 & 0.11 \\
\hline Tangibility & 155,597 & 0.29 & 0.10 & 0.25 & 0.43 & 0.22 \\
\hline Leverage & 155,369 & 0.18 & 0.00 & 0.12 & 0.31 & 0.19 \\
\hline ShortLev & 155,148 & 0.08 & 0.00 & 0.02 & 0.12 & 0.11 \\
\hline Profitability & 155,151 & 0.07 & 0.02 & 0.05 & 0.11 & 0.10 \\
\hline $\mathrm{Cfw}$ & 154,967 & 0.09 & 0.04 & 0.08 & 0.13 & 0.09 \\
\hline
\end{tabular}

Source: our elaboration on Amadeus data 
Figure 4: Descriptive Statistics by Firm Size and Year
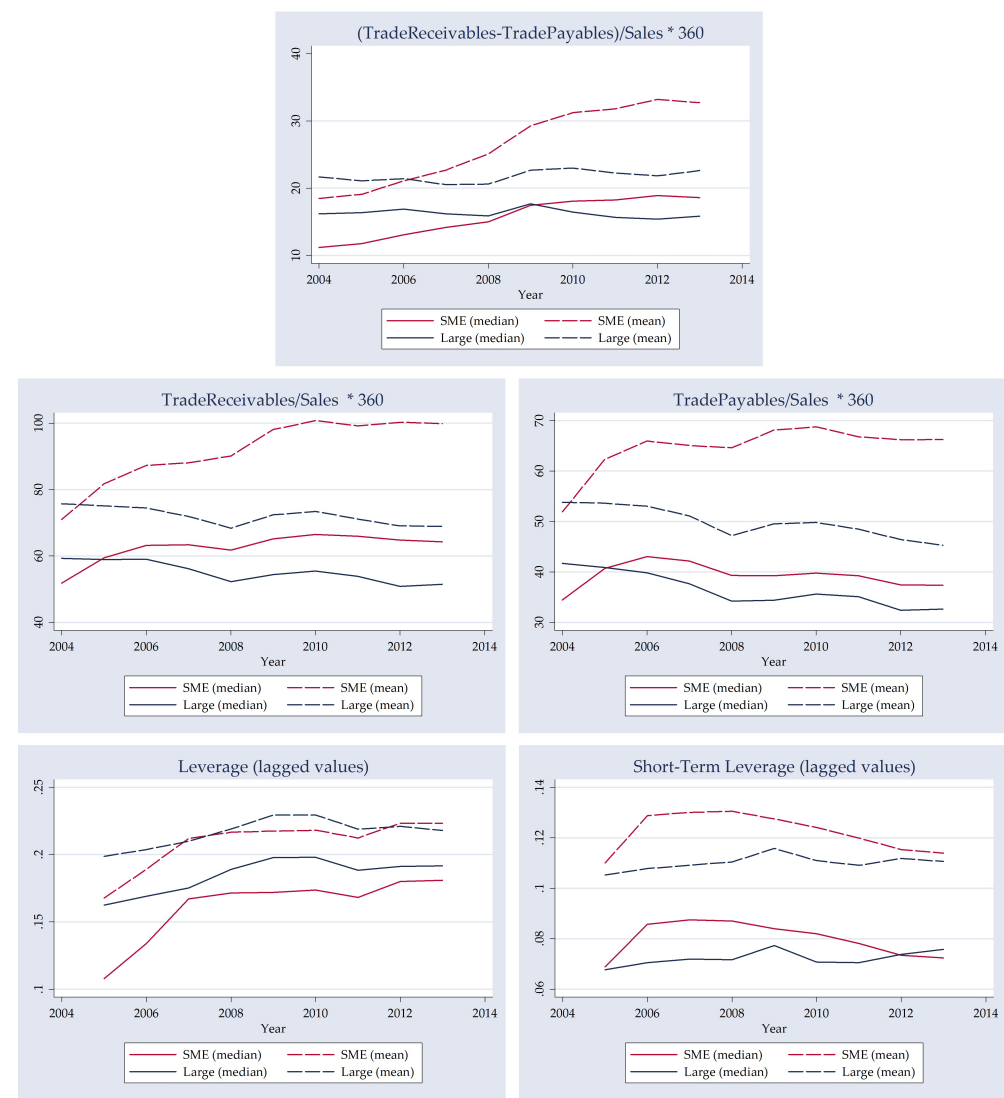

Our elaboration on AMADEUS data

\subsubsection{Net trade credit and time-varying characteristics of the firms}

Looking at the behavior of trade credit over time, Fig. 4 suggests that the dynamics of net trade credit has been different across firms of different size. In the ten years considered, net trade credit shows a much stronger increase for SMEs than for large firms. Furthermore, there is much larger asymmetry in the distribution of net trade credit in SMEs than in large firms, as shown by the larger difference between the mean and median values. In addition, these differences increase as a result of the crisis.

Empirical data show that the increase of NTCS among SMEs is mostly due 
to an increase of account receivables relative to sales, which is not accompanied by a corresponding increase in the ratio of account payables to sales. By contrast, in large firms both receivables and payables tend to decrease with respect to sales, and thus NTCS remains essentially stable. Therefore, the extension of credit maturity penalizes only SMEs.

Fig. 4 also shows the behavior of Leverage and ShortLev (Short-Term Leverage) within the same sample. Interestingly, SMEs are characterized by a decline in Short-Term Leverage in the crisis years, which signals that the increase in net receivables of SMEs takes place in a context of increasing pressure on liquidity needs induced by the reduction on bank loans.

In Table 2, we report as well the results of an ANOVA analysis that permits to better quantify the changes in trade credit over time (see Love, Preve and SarriaAllende, 2007). Specifically, we compare the pre-crisis years 2005-2007 with different periods during the crisis: 2008 as the starting year of the global financial crisis; 2009 as the year with major negative effects on the real economy; 20102011 as the initial recovery period; 2012-2013 as a second stage of difficulties for many countries, particularly in Europe's periphery. The analysis is conducted separately for SMEs and large firms.

Results from the ANOVA analysis confirm that the increase in net trade credit with respect to pre-crisis years is much larger among SMEs than in large companies and it is mostly due to the increase in receivables-to-sales ratios. The increase among SMEs is statistically significant starting from 2008 and continuously increases until 2012-2013. By contrast, the marginal increase among large companies attenuates after 2009 and its statistical significance declines.

Variables in the ANOVA analysis are all expressed in number of days. This implies that for SMEs the increase in NTCS reaches almost 12 days in 2012-2013, which corresponds to an increase of approximately 55 percent compared to precrisis levels.

The dynamics of NTCS for SMEs is dominated by the increase in receivables, coupled with a substantial stability of payables. For large firms, the fall in receivables is consistent with findings in Love, Preve and Sarria-Allende (2007). However, in contrast with their analysis, showing an increase in payables, we find that large firms reduced as well their payables.

In the next paragraph, we introduce a more detailed econometric analysis in order to identify the determinants of the dynamics of net trade credit across firms and years. 
Table 2: ANOVA Analysis

\begin{tabular}{|c|c|c|c|c|}
\hline \multicolumn{5}{|c|}{ SMEs } \\
\hline Variable & $\begin{array}{r}2008 \\
\text { vs. } \\
\text { Pre-Crisis }\end{array}$ & $\begin{array}{r}2009 \\
\text { vs. } \\
\text { Pre-Crisis }\end{array}$ & $\begin{array}{r}2010-2011 \\
\text { vs. } \\
\text { Pre-Crisis }\end{array}$ & $\begin{array}{r}2012-13 \\
\text { vs. } \\
\text { Pre-Crisis }\end{array}$ \\
\hline Receivables/Sale & $\begin{array}{l}4.0097 \\
(0.000)\end{array}$ & $\begin{array}{r}11.9603 \\
(0.000)\end{array}$ & $\begin{array}{r}13.7631 \\
(0.000)\end{array}$ & $\begin{array}{r}13.9529 \\
(0.000)\end{array}$ \\
\hline Payables/Sales & $\begin{array}{r}-0.0151 \\
(1.000)\end{array}$ & $\begin{array}{l}3.4713 \\
(0.000)\end{array}$ & $\begin{array}{l}3.0459 \\
(0.000)\end{array}$ & $\begin{array}{l}1.6015 \\
(0.000)\end{array}$ \\
\hline NTCS & $\begin{array}{l}3.8980 \\
(0.000)\end{array}$ & $\begin{array}{c}8.0600 \\
(0.000)\end{array}$ & $\begin{array}{r}10.3310 \\
(0.000)\end{array}$ & $\begin{array}{r}11.7512 \\
(0.000)\end{array}$ \\
\hline \multicolumn{5}{|c|}{ Large companies } \\
\hline Variable & $\begin{array}{r}2008 \\
\text { vs. } \\
\text { Pre-Crisis }\end{array}$ & $\begin{array}{r}2009 \\
\text { vs. } \\
\text { Pre-Crisis }\end{array}$ & $\begin{array}{r}2010-2011 \\
\text { vs. } \\
\text { Pre-Crisis }\end{array}$ & $\begin{array}{r}\text { 2012-13 } \\
\text { vs. } \\
\text { Pre-Crisis }\end{array}$ \\
\hline Receivables/Sale & $\begin{array}{r}-5.2746 \\
(0.000)\end{array}$ & $\begin{array}{r}-1.2676 \\
(0.605)\end{array}$ & $\begin{array}{r}-1.3743 \\
(0.122)\end{array}$ & $\begin{array}{r}-4.6537 \\
(0.000)\end{array}$ \\
\hline Payables/Sales & $\begin{array}{r}-5.2643 \\
(0.000)\end{array}$ & $\begin{array}{r}-2.9362 \\
(0.000)\end{array}$ & $\begin{array}{r}-3.3143 \\
(0.000)\end{array}$ & $\begin{array}{r}-6.5904 \\
(0.000)\end{array}$ \\
\hline NTCS & $\begin{array}{r}-0.3664 \\
(1.000)\end{array}$ & $\begin{array}{r}1.6873 \\
(0.039)\end{array}$ & $\begin{array}{c}1.6468 \\
(0.005)\end{array}$ & $\begin{array}{l}1.2302 \\
(0.075)\end{array}$ \\
\hline
\end{tabular}

The two tables report the difference in means between the periods indicated in each column and the pre-crisis years 2005-2007. The corresponding p-values, computed using the Bonferroni-adjusted significance level, are reported in parenthesis. 


\subsection{Baseline regressions}

In line with Love, Preve and Sarria-Allende (2007), we start with a simple model, which is estimated with firm-fixed effects.

The basic model is as follows:

$$
\operatorname{NTCS}_{i, t}=\alpha_{i}+\sum_{j=1,2} \beta_{j} \cdot \text { Period }_{j}+\beta_{3} \cdot X_{i, t-1}+\varepsilon_{i, t}
$$

where $\alpha_{i}$ and $\varepsilon_{i, t}$ represent respectively a firm fixed effect and the error term. $X_{i, t-1}$ is the set of control variables that we introduced in section 3.2 (see Table 1). All variables in $X_{i, t-1}$ have a one-year lag to reduce endogeneity problems. Period $_{1}$ is the dummy variable for the period 2008-2011, which isolates the initial period of the financial crisis. Period $_{2}$ is a second dummy for the next time period, 2012-2013, characterized by a second stage of recessions and financial turmoil, associated with the sovereign debt crisis. The basic model compares NTCS in 2008-2011 and 2012-2013 with NTCS in the pre-crisis years 2005-2007, after controlling for some time-variant firm characteristics.

We estimate the basic model separately for SMEs and large firms. Table 3 presents the results. Standard errors are obtained after clustering errors on country and time, in order to take into account possible correlation among error terms within each country-year pair.

The inclusion of firm fixed effects does not alter the results of the previous graphical and ANOVA analyses. NTCS significantly increases in crisis years, especially among SMEs. In 2012-2013 there is a further increase which affects only SMEs, while in large companies NTCS returns to pre-crisis levels.

Moreover, the main results do not change when we include control variables (columns 2 and 4). Coefficients on Cash and Tangibility are negative, while the coefficient on Leverage is positive. All else equal, an increase in liquidity and tangible assets predicts a lower willingness of the firm to provide trade credit or its higher need of external financing from suppliers. An increase in Leverage anticipates exactly the opposite behavior.

The positive coefficient on $C f w$ implies that, ceteris paribus, larger cash flow is associated with higher ability to extend trade credit to customers, relative to trade credit received from suppliers. The negative coefficient on Profitability in the regression for SMEs (column 4) may seem counter-intuitive, but it could signal that businesses losing profitability are more willing to extend credit in order to retain customers. This result is not new in the literature on trade credit, as 
Table 3: Basic regressions

\begin{tabular}{|c|c|c|c|c|}
\hline \multicolumn{5}{|c|}{ Dependent Variable: NTCS } \\
\hline & \multicolumn{2}{|c|}{ Large Companies } & \multicolumn{2}{|c|}{ SMEs } \\
\hline & $(1)$ & (2) & (3) & (4) \\
\hline Y2008-2011 & $\begin{array}{c}1.44^{*} \\
{[0.76]}\end{array}$ & $\begin{array}{l}1.50^{* *} \\
{[0.73]}\end{array}$ & $\begin{array}{l}8.44^{* * *} \\
{[2.07]}\end{array}$ & $\begin{array}{l}8.34^{* * *} \\
{[2.07]}\end{array}$ \\
\hline Y2012-2013 & $\begin{array}{c}0.47 \\
{[1.00]}\end{array}$ & $\begin{array}{c}0.76 \\
{[0.93]}\end{array}$ & $\begin{array}{l}15.25^{* * *} \\
{[3.14]}\end{array}$ & $\begin{array}{l}15.18^{* * *} \\
{[3.05]}\end{array}$ \\
\hline Cash (lag) & & $\begin{array}{c}-17.21^{* * *} \\
{[3.45]}\end{array}$ & & $\begin{array}{c}-15.11^{* * *} \\
{[3.06]}\end{array}$ \\
\hline Tangibility (lag) & & $\begin{array}{c}-21.51^{* * *} \\
{[2.99]}\end{array}$ & & $\begin{array}{c}-26.72^{* * *} \\
{[3.18]}\end{array}$ \\
\hline Profitability (lag) & & $\begin{array}{l}10.57^{* * *} \\
{[2.98]}\end{array}$ & & $\begin{array}{c}-6.35^{* *} \\
{[2.84]}\end{array}$ \\
\hline Cfw (lag) & & $\begin{array}{l}8.92^{* *} \\
{[3.99]}\end{array}$ & & $\begin{array}{l}16.65^{* * *} \\
{[2.96]}\end{array}$ \\
\hline Leverage (lag) & & $\begin{array}{l}14.77^{* * *} \\
{[2.19]}\end{array}$ & & $\begin{array}{l}17.03^{* * *} \\
{[2.34]}\end{array}$ \\
\hline Firm F.E. & YES & YES & YES & YES \\
\hline $\mathrm{N}$ & 146,062 & 140,952 & $7,422,076$ & $6,964,200$ \\
\hline $\mathrm{r} 2$ & 0.74 & 0.75 & 0.73 & 0.75 \\
\hline
\end{tabular}

Cluster-robust standard errors in brackets, after clustering by countryyear. The set of dummies includes fixed effects by firm (coefficients not reported). 
emphasized in Petersen and Rajan (1997). ${ }^{14}$

\subsection{Empirical analysis of heterogeneous firm responses}

The primary objective of our analysis is to assess how firm characteristics may affect the dynamics of net credit during the crisis. The behavior of trade credit at the firm level can vary depending on three dimensions: firms, country and industry. Consequently, our analysis is complicated by the fact that not all the explanatory variables that we are interested in are measured at the firm level. Mixed variables that are defined at different levels (i.e. that are not unique among firms within the same country or industry) may lead our regressions to underestimate the true standard deviations (Moulton, 1986) and may thus lead to an incorrect computation of the statistical significance of the coefficients.

We address this issue by implementing a two-step estimation approach, as suggested by Angrist and Pischke (2008). In the first stage, we estimate the impact of firm-level characteristics on the heterogeneous dynamics of NTCS, controlling for country, industry, country-period and industry-period fixed effects. In the second stage, which is based on a standard OLS model, we focus on the influence of country-level and industry-level characteristics on NTCS. Indeed, the dependent variables of the second stage are the coefficients of the country-period dummies and industry-period dummies that are estimated in the first stage.

In the first step, we introduce a vector of regressors defined at different levels:

a. firm-level fixed effects $\alpha_{i}$, which automatically incorporate time-invariant or slowly changing characteristics (such as country, industry and size);

b. the two period dummies, Period $_{1}$ and Period $_{2}$, respectively indicating the time intervals 2008-2011 and 2012-2013;

c. period-varying country dummies, obtained as the interaction term between Period $_{j}$ and Country $_{z}$;

d. period-varying industry dummies, obtained as the interaction term between Period $_{j}$ and Industry ; $_{\text {; }}$

e. firm-level time-varying firm characteristics, represented by the set of lagged control variables $X_{i, t-1}$ already introduced in our basic regressions;

\footnotetext{
${ }^{14}$ Petersen and Rajan (1997) state that "firms in trouble may use the extension of credit to attempt to maintain their sales. This leads to a possible explanation of why profits are negatively correlated with receivables".
} 
f. the interaction of period dummies Period $_{j}$ with time-varying firm characteristics, such as Leverage $e_{i, t-1}$ and $C f w_{i, t-1}$, or alternatively with timeinvariant firm characteristics, such as dummy variables $\mathrm{Size}_{l}$ distinguishing firms across 4 size classes (micro, small, medium and large).

The estimated coefficients on the interaction terms in (f) explain how changes in NTCS depend on relevant characteristics at the micro level, including firms' financial position and their size class. Table 4 presents the results of the first stage regressions.

In line with the results of our basic regressions, period dummies (non reported in the table) indicate that, ceteris paribus, NTCS is about 9.5 days higher in 20082011 with respect to pre-crisis years and 17 days higher in 2012-2013. Even the estimated coefficients on time-varying firm characteristics are consistent with basic regressions.

Columns 1 and 2 show the heterogeneous dynamics of NTCS for firms in different size classes. ${ }^{15}$ Column 2, in particular, reveals that the inclusion of control time-dependent variables does not change the results obtained in Column 1. The dummy for the Micro size class is omitted, so that the coefficients on the interaction term represent the differential effects with respect to the lowest size class. The coefficients on the interaction terms become more negative as we pass from smaller size classes to larger ones. This result seems to confirm that in crisis years 2008-2011 inter-enterprise credit tends to drain more financial resources than before the crisis from smaller firms to the benefit of larger companies. In 2012-2013 this heterogeneous impact of size classes on trade credit becomes stronger.

The differential impact of size classes on the dynamics of NTCS may not reflect a pure size effect, but effects associated with characteristics that are strongly correlated with firm size. Among these characteristics, two could be potentially relevant. The first is firm age. Interestingly, when substituting Age quintiles to the Size dummies, we do not obtain an equally significant differential effect. This suggests that the differential effect across size classes cannot be attributed to an implicit comparison of younger firms versus more established companies. The second characteristic that could be strongly correlated with firm size is the market power of individual firms. From the Amadeus dataset we do not have informa-

\footnotetext{
${ }^{15}$ The size of firms included in the dataset is inevitably linked to the distribution of the sample across different industries and countries. Therefore, the inclusion in our regressions of fixed effects by firm, country-period and industry-period is necessary in order to distinguish issues involving the size of a firm (SMEs vs. large companies) from issues related to other specific characteristics of individual industries or countries.
} 


\section{Table 4: Heterogeneous firm responses}

\begin{tabular}{|c|c|c|c|c|}
\hline \multicolumn{5}{|l|}{ Dependent Variable: NTCS } \\
\hline & (1) & (2) & (3) & (4) \\
\hline Y2008-2011*Small & $\begin{array}{c}-2.61^{\text {*** }} \\
{[0.14]}\end{array}$ & $\begin{array}{c}-2.49^{* * *} \\
{[0.14]}\end{array}$ & & \\
\hline Y2008-2011*Medium & $\begin{array}{c}-7.92^{* * *} \\
{[0.22]}\end{array}$ & $\begin{array}{c}-7.70^{* * *} \\
{[0.22]}\end{array}$ & & \\
\hline Y2008-2011*Large & $\begin{array}{c}-9.49^{* * *} \\
{[0.32]}\end{array}$ & $\begin{array}{c}-9.55^{* * *} \\
{[0.32]}\end{array}$ & & \\
\hline Y2012-2013*Small & $\begin{array}{c}-5.45^{* * *} \\
{[0.18]}\end{array}$ & $\begin{array}{c}-5.31^{* * *} \\
{[0.18]}\end{array}$ & & \\
\hline Y2012-2013*Medium & $\begin{array}{c}-14.77^{* * *} \\
{[0.29]}\end{array}$ & $\begin{array}{c}-14.64^{* * *} \\
{[0.29]}\end{array}$ & & \\
\hline Y2012-2013*Large & $\begin{array}{c}-16.73^{* * *} \\
{[0.41]}\end{array}$ & $\begin{array}{c}-16.91^{* * *} \\
{[0.42]}\end{array}$ & & \\
\hline Cfw (lag) & & $\begin{array}{l}16.41^{* * *} \\
{[0.72]}\end{array}$ & & $\begin{array}{l}16.33^{* * *} \\
{[0.72]}\end{array}$ \\
\hline Y2005-2007*Cfw(lag) & & & $\begin{array}{l}14.19^{* * *} \\
{[0.81]}\end{array}$ & \\
\hline Y2008-2011*Cfw(lag) & & & $\begin{array}{l}15.99^{* * *} \\
{[0.77]}\end{array}$ & \\
\hline Y2012-2013*Cfw(lag) & & & $\begin{array}{l}19.75^{* * *} \\
{[0.87]}\end{array}$ & \\
\hline Leverage (lag) & & $\begin{array}{l}13.74^{* * *} \\
{[0.29]}\end{array}$ & $\begin{array}{l}13.73^{* * *} \\
{[0.29]}\end{array}$ & \\
\hline Y2005-2007*Leverage(lag) & & & & $\begin{array}{l}17.64^{* * *} \\
{[0.38]}\end{array}$ \\
\hline Y2008-2011*Leverage(lag) & & & & $\begin{array}{l}13.86^{* * *} \\
{[0.33]}\end{array}$ \\
\hline Y2012-2013*Leverage(lag) & & & & $\begin{array}{l}7.13^{* * *} \\
{[0.43]}\end{array}$ \\
\hline Cash (lag) & & $\begin{array}{c}-13.72^{* * *} \\
{[0.28]}\end{array}$ & $\begin{array}{c}-13.73^{* * *} \\
{[0.28]}\end{array}$ & $\begin{array}{c}-13.82^{* * *} \\
{[0.28]}\end{array}$ \\
\hline Tangibility (lag) & & $\begin{array}{c}-27.93^{* * *} \\
{[0.40]}\end{array}$ & $\begin{array}{c}-28.16^{* * *} \\
{[0.40]}\end{array}$ & $\begin{array}{c}-28.02^{* * *} \\
{[0.40]}\end{array}$ \\
\hline Profitability (lag) & & $\begin{array}{c}-6.36^{* * *} \\
{[0.60]}\end{array}$ & $\begin{array}{c}-6.44^{* * *} \\
{[0.60]}\end{array}$ & $\begin{array}{c}-6.32^{* * * *} \\
{[0.60]}\end{array}$ \\
\hline Firm F.E. & YES & YES & YES & YES \\
\hline Period F.E. & YES & YES & YES & YES \\
\hline Country-Period F.E. & YES & YES & YES & YES \\
\hline Industry-Period F.E. & YES & YES & YES & YES \\
\hline $\mathrm{N}$ & $7,415,613$ & $6,938,083$ & $6,938,083$ & $6,938,083$ \\
\hline $\mathrm{r} 2$ & 0.71 & 0.72 & 0.72 & 0.72 \\
\hline
\end{tabular}


tion on the customers and suppliers of each individual firm and their relative sizes and/or market shares. However, to capture the potential role of market power in the customer-supplier relationship, we use information from Input-Output (I-O) Tables and from data from Eurostat on the share of large companies within each industry. We perform this type of analysis in Section 3.5, in which we investigate the different impact of net trade credit at the industry level.

Finally, Column 3 shows the heterogeneous behavior of NTCS during the crisis in relation to the capacity of cash flow generation by firms. The positive coefficients on the interaction term increase over time, suggesting that $C f w$ determines an increasing heterogeneity in NTCS. This is broadly in line with Love, Preve and Sarria-Allende (2007), according to which financial crises lead to larger increases of NTCS among firms with a higher (lagged) cash flow.

By contrast, Column 4 shows that the positive coefficients on leverage decrease over time. Presumably, increasing dependence on bank credit may be a sign of weaker financial conditions in times of financial crises. Consequently, the positive impact that easier access to bank credit exerts on NTCS becomes weaker in the post-crisis period. Ceteris paribus, firms increasing their indebtedness are not more willing to extend trade credit to their customers, net of the credit they receive from suppliers.

This effect has also been emphasized by Love, Preve and Sarria-Allende (2007) for the case of the Asian and Mexican crises of the 1990s. A possible explanation is that with idiosyncratic liquidity shocks, firms with access to outside liquidity are the only ones that can stop the propagation of the shock with their deep pockets. However, if the crisis originates in the financial system, firms more dependent on bank credit may be those that propagate the shock through supply chains.

One possible objection to our analysis is that firm size may not be a relevant factor for firms belonging to industrial groups. The Amadeus database does not contain direct information on whether a firm belongs or not to a group. However, our analysis above has been based on data from consolidated balance sheets and therefore it nets out intra-group transactions. Nevertheless, we provide a further robustness check to our results by using the "degree of independence" indicator contained in Amadeus, which classifies firms on the basis of the share in the capital owned by other firms. Table 11 in Appendix A.1 reports results for the most independent firms, namely firms that do not have shareholders with more than 25 percent of firms capital. Results do not change for such subgroup of firms. Furthermore, we run the same regression for the sample of firms with shares of outside firms on their capital not larger than 50 percent and again results go through. In conclusion, we claim that our results are not affected by cross-controls of firms 
with potential suppliers/customers.

Finally, in Appendix A.2 we show that results do not change if we split the sample on the basis of the degree of access to external financing of individual firms. To select the most and the least financially constrained firms, we adopt a stylized credit scoring system along the the lines of Altman and Hotchkiss (2005) and Altman and Sabato (2007). ${ }^{16}$

\subsubsection{Payables and Receivables}

Our main focus is on Net Trade Credit and its role in the liquidity transmission channel across firms. It is nevertheless worth investigating whether the behavior of NTCS derives mainly from the behavior of receivables or of payables. This is also relevant to disentangle pure demand effects from other channels. Indeed, one possible reason for the increase in NTCS could be a fall in payables associated to a fall in purchases of inputs. However, if the increase is mainly due to an increase in receivables, such demand channel is not crucial. Furthermore, we can directly verify our conjecture on the high degree of circularity in trade credit, with receivables being strongly correlated to payables at the firm level. We first analyze whether Kim and Shin (2012) hypothesis of the presence of a countryspecific Cobb-Douglas relationship between firms' receivables and payables and sales holds in our sample covering an episode of financial crisis. Indeed, in Table 5 we find evidence of such a Cobb-Douglas functional form, as the coefficients on payables and sales in a cross-section regression of receivables sum up to one. Interestingly, such a form is rather stable as it does not significantly change during the crisis period. ${ }^{17}$ An important implication of this stability result is that the main channel highlighted by Kim and Shin (2012) seems to represent a stable structural characteristic explaining different levels of trade credit across countries, but it cannot account for changes taking place during financial crises.

We now turn to the analysis to the behavior of payables and receivables at the firm level within the same framework we used to estimate the behavior of net trade credit. Table 6 presents the results obtained focusing on the heterogeneous dynamics of receivables and payables for firms in different size classes. The es-

\footnotetext{
${ }^{16}$ The relevant objective here is not to get an optimal scoring system but to distinguish two subsamples of firms that are well differentiated with respect to their relative ability to access external financing.

${ }^{17}$ As shown in Appendix A.3 (Table 13), differences across countries in the coefficients on payables and on sales are large, suggesting significant differences in the industrial structures and in financial arrangements across countries.
} 
Table 5: Receivables, payables and sales

\begin{tabular}{|c|c|c|c|c|}
\hline \multicolumn{5}{|c|}{ Dependent variable: $\log$ receivables } \\
\hline Year & log payables & $\log$ sales & $R^{2}$ & Obs. \\
\hline 2007 & 0.348 & 0.603 & 0.78 & 591,733 \\
\hline 2008 & 0.343 & 0.605 & 0.78 & 591,733 \\
\hline 2009 & 0.354 & 0.587 & 0.77 & 591,733 \\
\hline 2010 & 0.365 & 0.577 & 0.77 & 591,733 \\
\hline 2011 & 0.364 & 0.575 & 0.77 & 591,733 \\
\hline 2012 & 0.365 & 0.565 & 0.77 & 591,733 \\
\hline 2013 & 0.370 & 0.555 & 0.77 & 591,733 \\
\hline
\end{tabular}

Cross-section OLS regression results from a balanced AMADEUS sample, after removing firms that did not report a positive figure for either receivables or payables.

timated model replicates the one estimated in Column 1 and Column 2 of Table 4, with the only difference that we introduce Payables to Sales (Receivables to Sales) as additional regressor when the dependent variable is Receivables to Sales (Payables to Sales).

Results from Table 6 reveal that the dynamics of NTCS by size classes works mainly through accounts receivable rather than accounts payable, with Receivables to Sales (Column 1 and 2) decreasing with firm size. Indeed, the coefficients on size classes have to be interpreted relative to the omitted Micro size class. By contrast, for Payables to Sales (Column 3 and 4), the differential effects through different size classes are positive but statistically insignificant. Therefore, during the financial crisis the drainage of financial resources from small businesses through inter-enterprise credit took place primarily through an increase in receivables.

To sum up, firms suffering financial problems (e.g. low ability to generate cash flow) tend to increase their Payables to Sales (i.e. they postpone their payments) regardless of their size, as revealed by the fact that the behavior of Payables to Sales does not significantly differ across size classes. By contrast, large firms have a higher capacity than small firms to extract prompt payments of credits from their customers.

Overall, results confirm the findings for NTCS, which indicate that firms with higher cash-flow and higher leverage tend to provide more trade credit during the 
Table 6: Heterogeneous firm responses - Receivables and Payables

\begin{tabular}{|c|c|c|c|c|}
\hline \multirow[t]{2}{*}{ Dependent Variable: } & \multicolumn{2}{|c|}{ Receivables to Sales } & \multicolumn{2}{|c|}{ Payables to Sales } \\
\hline & (1) & (2) & (3) & (4) \\
\hline Y2008-2011*Small & $\begin{array}{c}-5.74^{* * *} \\
{[0.20]}\end{array}$ & $\begin{array}{c}-5.36^{* * *} \\
{[0.19]}\end{array}$ & $\begin{array}{c}-1.05^{* * *} \\
{[0.17]}\end{array}$ & $\begin{array}{c}-1.01^{* * *} \\
{[0.17]}\end{array}$ \\
\hline Y2008-2011*Medium & $\begin{array}{c}-12.35^{* * *} \\
{[0.31]}\end{array}$ & $\begin{array}{c}-11.94^{* * *} \\
{[0.31]}\end{array}$ & $\begin{array}{l}1.30^{* * *} \\
{[0.28]}\end{array}$ & $\begin{array}{l}1.17^{* * *} \\
{[0.27]}\end{array}$ \\
\hline Y2008-2011*Large & $\begin{array}{c}-13.90^{* * * *} \\
{[0.43]}\end{array}$ & $\begin{array}{c}-13.84^{* * * *} \\
{[0.42]}\end{array}$ & $\begin{array}{l}1.53^{* * *} \\
{[0.39]}\end{array}$ & $\begin{array}{l}1.78^{* * *} \\
{[0.37]}\end{array}$ \\
\hline Y2012-2013*Small & $\begin{array}{c}-11.50^{* * *} \\
{[0.26]}\end{array}$ & $\begin{array}{c}-10.94^{* * *} \\
{[0.26]}\end{array}$ & $\begin{array}{c}-1.41^{* * *} \\
{[0.21]}\end{array}$ & $\begin{array}{c}-1.28^{* * *} \\
{[0.21]}\end{array}$ \\
\hline Y2012-2013*Medium & $\begin{array}{c}-23.85^{* * *} \\
{[0.41]}\end{array}$ & $\begin{array}{c}-23.28^{* * *} \\
{[0.41]}\end{array}$ & $\begin{array}{l}1.68^{* * *} \\
{[0.34]}\end{array}$ & $\begin{array}{l}1.59^{* * *} \\
{[0.34]}\end{array}$ \\
\hline Y2012-2013*Large & $\begin{array}{c}-25.79^{* * *} \\
{[0.59]}\end{array}$ & $\begin{array}{c}-25.56^{* * * *} \\
{[0.58]}\end{array}$ & $\begin{array}{l}1.97^{* * *} \\
{[0.49]}\end{array}$ & $\begin{array}{l}2.50^{* * *} \\
{[0.48]}\end{array}$ \\
\hline PayablesToSales & $\begin{array}{l}0.44^{* * *} \\
{[0.00]}\end{array}$ & $\begin{array}{l}0.46^{* * *} \\
{[0.00]}\end{array}$ & & \\
\hline ReceivablesToSales & & & $\begin{array}{l}0.33^{* * *} \\
{[0.00]}\end{array}$ & $\begin{array}{l}0.33^{* * *} \\
{[0.00]}\end{array}$ \\
\hline Cfw (lag) & & $\begin{array}{l}7.81^{* * *} \\
{[1.10]}\end{array}$ & & $\begin{array}{c}-19.11^{* * *} \\
{[0.92]}\end{array}$ \\
\hline Leverage (lag) & & $\begin{array}{l}11.49^{* * *} \\
{[0.44]}\end{array}$ & & $\begin{array}{c}-14.44^{* * *} \\
{[0.38]}\end{array}$ \\
\hline Cash (lag) & & $\begin{array}{c}-23.21^{* * *} \\
{[0.41]}\end{array}$ & & $\begin{array}{l}2.74^{* * *} \\
{[0.33]}\end{array}$ \\
\hline Tangibility (lag) & & $\begin{array}{c}-40.25^{* * *} \\
{[0.62]}\end{array}$ & & $\begin{array}{l}11.55^{* * * *} \\
{[0.57]}\end{array}$ \\
\hline Profitability (lag) & & $\begin{array}{c}-15.68^{* * *} \\
{[0.92]}\end{array}$ & & $\begin{array}{c}-7.00^{* * *} \\
{[0.76]}\end{array}$ \\
\hline Firm F.E. & YES & YES & YES & YES \\
\hline Period F.E. & YES & YES & YES & YES \\
\hline Country-Period F.E. & YES & YES & YES & YES \\
\hline Industry-Period F.E. & YES & YES & YES & YES \\
\hline $\mathrm{N}$ & $7,395,828$ & $6,920,875$ & $7,395,828$ & $6,920,875$ \\
\hline $\mathrm{r} 2$ & 0.73 & 0.74 & 0.70 & 0.71 \\
\hline
\end{tabular}

Robust standard errors in brackets. The set of dummies includes fixed effects by firm, period, country-period and industry-period (coefficients not reported). 
crisis, by increasing their receivables and decreasing their payables. Finally, a positive and highly significant correlation between receivables and payables confirms the presence of a degree of circularity in inter-enterprise credit, though far from perfect as the coefficients are around 0.45 in the regressions for payables and 0.33 in the regressions for receivables.

In the following sections, the estimated coefficients on the industry-period and country-period dummies obtained in the first stage regressions are used to create the dependent variable of the second stage of the analysis, which aims to identify the determinants of cross-industry and cross-country heterogeneity in the dynamics of NTCS. Fixed effects by country-period and industry-period represent a measure of $N T C S$ that is appropriately cleaned from the influence of heterogeneity at the firm level. The second stage is based on standard OLS regressions, which include specific regressors that may possibly differentiate industries and countries in the dynamics of NTCS around the crisis years.

\subsection{Heterogeneous impact on $N T C S$ by industry}

In this section, we concentrate on the heterogeneity by industry. The estimated coefficients that we use to build our dependent variable are those obtained from the regression represented in Column 2 of Table 4, referring to the first stage regressions. For each industry $k$ in period $j$, we take the sum of the coefficient on Period $_{j}$ and of the coefficient on the interaction term Industry I $_{k} \cdot$ Period $_{j}{ }^{18}$ Then, for both Period $_{1}$ (years 2008-2011) and Period $_{2}$ (2012-2013) we compute the differences of each industry-period term with respect to the pre-crisis period (years 2005-2007).

Let us consider the period 2012-2013. After excluding one single very influential observation, that actually refers to an exceptionally peculiar industry (i.e. Manufacture of Military Fighting Vehicles), we have 198 measures at the industry level, which represent the change in NTCS with respect to the pre-crisis years 2005-2007. Since the first stage regression served to filter out firm-level characteristics, the new dependent variables can be interpreted as reflecting the representative firm in each industry. These dependent variables range from a minimum of -19.8 days for the Manufacture of Tobacco Products to a maximum of 40.1 days for the Development of Building Projects.

\footnotetext{
${ }^{18}$ Since we estimate separate cross-industry regressions for $\operatorname{Period}_{1}$ and for $\operatorname{Period}_{2}$, we could limit our analysis to the coefficients on the interaction term, because the coefficient on Period $_{j}$ is constant within each period $j$. However, considering the sum of the two terms helps to clarify the economic meaning of our dependent variable.
} 
All the values of $\triangle N T C S$ by NACE industry are listed in Appendix B.3 (Table 18). Mean and median values are very similar and slightly smaller than 14 days, while the standard deviation is equal to 8.1 days. This means that on average NTCS in the period 2012-13 was about 14 days higher than in the pre-crisis years. Similar results apply to the period 2008-2011. In this case, the dependent variable ranges from a minimum of -13.5 days for the Manufacture of Tobacco Products to a maximum of 23.3 days for the Development of Building Projects. Mean and median values are still very similar and slightly larger than 8 days, while the standard deviation is equal to 4.8 days. For both post-crisis periods, relative to pre-crisis years, there is heterogeneity in the dynamics of NTCS and such heterogeneity is larger in 2012-2013 than in 2008-2011.

The second-stage analysis can shed light on two main issues discussed in Section 3.2. First, the degree of upstreamness of sectoral production may have significant effects on the probability that a firm is, for technological reasons, a net debtor or net creditor in the trade credit market. The relevant question is whether such degree of upstreamness helps to explain the behavior of net credit in the aftermath of the crisis. We find that upstreamness does not have a statistically significant effect on the net credit position at the sectoral level. ${ }^{19}$ Therefore, although upstreamness helps to explain the heterogeneous levels of NTCS across industries, it does not seem to have a significant influence on the heterogeneous changes in NTCS that followed the crisis.

Second, one of the main aspects of our analysis aims at capturing whether different bargaining power between firms in their customer-supplier relationship affects the behavior of net trade credit during the crisis period. As noted earlier, we do not have information at the firm level on the characteristics of their customers or suppliers. To shed light on this issue, we combine two sets of information at the sectoral level to derive the variable RelativeSize, which is given by the difference between the percentage of large firms within each industry and the weighted average of the percentage of large companies within the supplier and customer industries of the industry itself. The weights are based on information obtained from the U.S. Input-Output (I-O) Tables from the Bureau of Economic Analysis (BEA). With respect to suppliers, the weights represent the relative importance of goods (or services) produced by each industry as an input for the industry considered. With respect to customers, the weights represent the relative importance of each industry as a consumer of goods (or services) produced by the industry considered.

\footnotetext{
${ }^{19}$ Results are not reported here, but are available upon request.
} 
We compute the percentages of large firms within each industry from data from the Eurostat Structural Business Statistics. These measures are based on Turnover figures in year 2013. ${ }^{20}$ For each industry, weighted averages of the percentage of large companies are separately obtained for the suppliers and the customers. Then we take a simple average of the two measures and subtract it from the percentage of large companies within the industry itself.

The values of RelativeSize across NACE industries are listed in Appendix B.4 (Table 19). The higher is this measure of RelativeSize the higher is the presence of large companies in the industry considered, relative to industries that constitute its main customers and suppliers. Therefore, RelativeSize should be a good proxy of bargaining power of the average firm in a given industry. In other words, if a firm is a supplier producing in sector $i$, which is a sector with low average size of firms, and it sells to firms in sector $j$, which is characterized by a much higher average size, we infer that the supplier in sector $i$ has a weak bargaining power with respect to its customer in sector $j$.

We also introduce the variable Weight_Households_Customers, which represents the relative weight of households as customers for the output of each industry. This measure as well is based on information from the Input-Output (I-O) Tables. Weight_Households_Customers can be partly assimilated to an upstreamness measure, since it assumes higher values in industries that are closer to the final customers. However, it only gives relevance to the last stage of the production process. From this point of view, Weight_Households_Customers is likely to capture an additional source of market power, i.e. the bargaining power of non-financial businesses with respect to individual households.

In addition, we consider the weighted average of the pre-crisis levels of leverage of customers (Leverage_Customers) and suppliers (Leverage_Suppliers) of each industry. The measure of pre-crisis leverage for each industry is based on AMADEUS data. First, we take the firm-level median of Leverage during the pre-crisis period 2004-2007. Then, the median of these measures is taken for each three-digit NACE industry in order to define the pre-crisis level of each industry for Europe as a whole. The weights used to obtain the weighted averages for customers and suppliers of each industry are those used to compute the Relativesize variable.

All these measures are built excluding industries that are outside the nonfinancial business economy and other specific industries. In order to control for

\footnotetext{
${ }^{20}$ The choice of the year should not affect this variable, assuming that the ranking with respect to percentages of large firms remains stable within the relatively short time interval of our analysis.
} 
the omission of possibly relevant information arising from this exclusion, we add further regressors that measure the weight of the excluded industries (Agriculture, Financial Activities and Other Activities) as customers for the output of each industry and, also, as suppliers for the inputs of the industry itself.

Table 7 reports the results of the second stage regressions with respect to industry-period observations.

Table 7: Heterogeneous responses by industry

\begin{tabular}{|c|c|c|c|c|}
\hline \multicolumn{5}{|c|}{ Dependent Variable: Changes in NTCS with respect to pre-crisis levels } \\
\hline & \multicolumn{2}{|c|}{ 2008-2011 vs. precrisis } & \multicolumn{2}{|c|}{ 2012-2013 vs. precrisis } \\
\hline & (1) & (2) & (3) & (4) \\
\hline RelativeSize & $\begin{array}{c}-4.90^{* * *} \\
{[1.75]}\end{array}$ & $\begin{array}{c}-5.08^{* * *} \\
{[1.85]}\end{array}$ & $\begin{array}{c}-8.62^{* * *} \\
{[2.26]}\end{array}$ & $\begin{array}{c}-7.98^{* * *} \\
{[2.39]}\end{array}$ \\
\hline Weight_Households_Customers & $\begin{array}{c}-6.06^{* * *} \\
{[1.33]}\end{array}$ & $\begin{array}{c}-6.12^{* * *} \\
{[1.59]}\end{array}$ & $\begin{array}{c}-14.09^{* * *} \\
{[2.06]}\end{array}$ & $\begin{array}{c}-14.24^{* * *} \\
{[2.54]}\end{array}$ \\
\hline Leverage_Customers & $\begin{array}{c}-59.50^{* * *} \\
{[14.61]}\end{array}$ & $\begin{array}{c}-59.16^{* * *} \\
{[16.32]}\end{array}$ & $\begin{array}{c}-140.67^{* * *} \\
{[20.80]}\end{array}$ & $\begin{array}{c}-140.49^{* * *} \\
{[24.03]}\end{array}$ \\
\hline Leverage_Suppliers & $\begin{array}{c}-37.87^{* * *} \\
{[12.76]}\end{array}$ & $\begin{array}{c}-78.61^{* * *} \\
{[26.35]}\end{array}$ & $\begin{array}{c}-79.00^{* * *} \\
{[17.76]}\end{array}$ & $\begin{array}{c}-87.36^{* * *} \\
{[33.05]}\end{array}$ \\
\hline Weight_Agriculture_Customers & & $\begin{array}{c}1.75 \\
{[2.48]}\end{array}$ & & $\begin{array}{c}-4.52 \\
{[4.30]}\end{array}$ \\
\hline Weight_Financial_Customers & & $\begin{array}{l}-5.89 \\
{[14.18]}\end{array}$ & & $\begin{array}{c}0.03 \\
{[24.38]}\end{array}$ \\
\hline Weight_Other_Customers & & $\begin{array}{c}-5.37 \\
{[4.35]}\end{array}$ & & $\begin{array}{c}-5.02 \\
{[6.02]}\end{array}$ \\
\hline Weight_Agriculture_Suppliers & & $\begin{array}{c}-8.80^{* *} \\
{[3.92]}\end{array}$ & & $\begin{array}{c}-8.07 \\
{[5.50]}\end{array}$ \\
\hline Weight_Financial_Suppliers & & $\begin{array}{c}-15.68 \\
{[10.23]}\end{array}$ & & $\begin{array}{c}0.62 \\
{[14.91]}\end{array}$ \\
\hline Weight_Other_Suppliers & & $\begin{array}{c}-10.61 \\
{[9.64]}\end{array}$ & & $\begin{array}{c}1.07 \\
{[10.41]}\end{array}$ \\
\hline _cons & $\begin{array}{l}15.93^{* * *} \\
{[1.29]}\end{array}$ & $\begin{array}{l}21.14^{* * *} \\
{[3.12]}\end{array}$ & $\begin{array}{l}30.73^{* * *} \\
{[1.87]}\end{array}$ & $\begin{array}{l}32.08^{* * *} \\
{[4.05]}\end{array}$ \\
\hline $\mathrm{N}$ & 198 & 198 & 198 & 198 \\
\hline $\mathrm{r} 2$ & 0.23 & 0.27 & 0.39 & 0.40 \\
\hline
\end{tabular}

The OLS regression strongly supports our priors. We find that the coefficient on RelativeSize is negative and highly significant. The higher is the measure of RelativeSize of a given industry, the more it is able to contain the increase in NTCS in the aftermath of the crisis. The negative coefficient on RelativeSize indicates that the bargaining power induced by market concentration and firms' 
size affects the dynamics of net trade credit in the aftermath of the crisis. This implies a redistribution of financial resources that is not driven by productivity and, consequently, a potential source of misallocation of resources.

Similarly, the negative coefficient on Weight_Households_Customers reveals that downstream industries in the last stage of production have a higher ability to contain their net trade credit by limiting the credit granted to households (whose bargaining power is limited) and possibly transferring liquidity problems to their suppliers.

Negative coefficients on Leverage_Customers and Leverage_Suppliers suggest that the possibility to contain the increase in net trade credit is higher for those industries whose customers and suppliers have an easier access to external finance, computed for the pre-crisis years. Therefore, even after the crisis, industries with higher access to outside liquidity can partially contribute to attenuate the propagation of liquidity shocks through their deep pockets. ${ }^{21}$

The inclusion of control variables (Columns 2 and 4) does not alter the main results of the analysis. ${ }^{22}$

\subsection{Heterogeneous impact on NTCS by country}

We carry out a similar second stage analysis now focusing on coefficients on the country fixed effects. The analysis here is more illustrative, as the sample size (25 countries) is much smaller than the one available for the industry-level analysis.

The dependent variable refers to the representative firms of individual countries and it represents the changes in NTCS in post-crisis years with respect to the pre-crisis years 2005-2007. Table 8 presents the results of the second stage regressions with respect to country-period observations.

For the cross-country second stage regression we introduce two regressors. The first regressor is a measure of the creditlessness nature of the post-crisis period for each country. This measure is based on domestic credit to the private sector as a ratio to GDP, computed from the World Bank database. We compute the average growth rate of Credit-to-GDP in the pre-crisis period 2003-2007 and then we compare it with the average growth rate in the period 2008-2011 (for the regression in Column 1) and in the period 2008-2013 (for the regression in Column 2). The difference gives respectively our measures of Creditlessness 11 and

\footnotetext{
${ }^{21}$ In line with Boissay and Gropp (2013).

${ }^{22}$ In addition, second stage regressions on payables and receivables broadly confirm the results and indicate that the main differences across small and large firms operate through receivables (see Tables 14 and 15 in Appendix A.3).
} 
Creditlessness 13. The higher is the value of creditlessness the higher is the fall in credit growth within a country. The coefficient on this variable is not statistically significant, implying that the availability of bank credit in the aftermath the crisis is not a main contributor of heterogeneity in the dynamics of net trade credit.

The second regressor is GDP growth at the country level. We consider the average GDP growth in the period 2008-2011 (for the regression in Column 1) and in the period 2008-2013 (for the regression in Column 2), respectively defined as GDPgrowth11 and GDPgrowth 13 in the table below. In this case the coefficients on GDP growth are statistically significant. The negative sign implies that NTCS increases more in countries where the recession has been more severe and the recovery slower. This may be a consequence of payment delays from final customers that propagate to all domestic firms along the production chain. One could define this generalized increase in NTCS as involuntary trade credit, reflecting default in payments rather than the voluntary extension of credit by the suppliers.

Table 8: Heterogeneous responses by country

\begin{tabular}{|c|c|c|}
\hline \multicolumn{3}{|c|}{ Dependent Variable: Changes in NTCS with respect to pre-crisis levels } \\
\hline & 2008-2011 vs. precrisis & 2012-2013 vs. precrisis \\
\hline & (1) & (2) \\
\hline Creditlessness 11 & $\begin{array}{r}-17.52 \\
{[19.29]}\end{array}$ & \\
\hline GDPgrowth11 & $\begin{array}{r}-177.48^{*} \\
{[98.81]}\end{array}$ & \\
\hline Creditlessness 13 & & $\begin{array}{l}-8.28 \\
{[18.94]}\end{array}$ \\
\hline GDPgrowth13 & & $\begin{array}{c}-475.52^{* * *} \\
{[138.63]}\end{array}$ \\
\hline _cons & $\begin{array}{l}11.76^{* * *} \\
{[2.24]}\end{array}$ & $\begin{array}{l}19.06^{* * *} \\
{[3.13]}\end{array}$ \\
\hline $\mathrm{N}$ & 25 & 25 \\
\hline $\mathrm{r} 2$ & 0.14 & 0.35 \\
\hline
\end{tabular}

Robust standard errors in brackets. 


\section{Trade credit and real adjustment}

In this section, we analyze the possible implications of changes in net trade credit on both investments and labor market variables during the Great Recession. Against the background of great difficulties for non-financial corporations in raising funds from banks and financial institutions, we want to verify whether the increase in NTCS added significant financial pressure on firms, forcing them to reduce both labor costs (through reduction in wages and/or employment), and investment in fixed capital or inventories. Having found that SMEs have been adversely affected in their liquidity through an increase in their net trade credit position, we assess whether such increase in NTCS has been associated with a disproportionate fall in both investments and wages/employment. The potential effects on employment by SMEs are particularly relevant as SMEs are a main source of employment in European economies. Furthermore, the fall in investments would signal a long-lasting negative effect on growth of SMEs resulting from a liquidity squeeze through trade credit.

In Table 9 we report the variation in the different items of firms' balance sheets during different phases of the global financial crisis. The sample is split in quintiles according to the variation of net trade credit to total assets within each subperiod. Descriptive statistics are shown separately for micro and small firms, on the one hand, and medium and large firms, on the other hand. Changes on the liability side of the budget are reported with reversed sign, so that the sign (-) indicates an increase of the share to total assets.

Table 9 shows that firms with the strongest increase in net trade credit (V quintile) tend to compensate the higher weight of trade credit in total assets with adjustments in all the other budget items. On the liability side, higher levels of debt and equity are needed in order to finance the increasing (decreasing) levels of receivables (payables). On the asset side, lower levels of inventories, cash holdings and fixed assets compensate for the liquidity squeeze transmitted through trade credit that is not counterbalanced with alternative sources of financing. This evidence suggests that the increase in NTCS drains liquid resources that firms could otherwise use for investment purposes or for the support of current production. Such liquidity drain affects both production capacity at the micro level and aggregate demand at the macro level.

Interestingly, financial debt is more easily available for medium and large firms than for micro and small firms as an instrument to compensate the liquidity squeeze operating through trade credit. As a consequence, micro and small firms with the highest increases in net trade credit need to rely more on alternative 
Table 9: Behavior of financing and investment items relative to net trade credit MEDIUM AND LARGE FIRMS

\begin{tabular}{|c|c|c|c|c|c|c|c|c|}
\hline \multirow[b]{3}{*}{ Period } & & \multicolumn{7}{|c|}{ Variation (p.p.) of the Shares in Total Assets of: } \\
\hline & & \multirow[b]{2}{*}{$\begin{array}{c}\text { Net Trade } \\
\text { Credit }\end{array}$} & \multicolumn{3}{|c|}{ Asset Side (+) } & \multicolumn{3}{|c|}{ Liability Side (-) } \\
\hline & & & Stocks & Cash & $\begin{array}{l}\text { Fixed } \\
\text { Assets }\end{array}$ & $\begin{array}{l}\text { Fin. } \\
\text { Debt }\end{array}$ & $\begin{array}{l}\text { Oth. } \\
\text { Liab. }\end{array}$ & $\begin{array}{c}\text { Sh. } \\
\text { Funds }\end{array}$ \\
\hline \multicolumn{9}{|c|}{ 2007-2009 } \\
\hline \multirow{3}{*}{ Quintile: } & $\mathrm{I}$ & -23.7 & 2.9 & 7.1 & 4.2 & 3.0 & 2.4 & 4.1 \\
\hline & III & 0.6 & -0.7 & 0.7 & 1.4 & 0.2 & -0.4 & -1.9 \\
\hline & $\mathrm{V}$ & 26.7 & -4.3 & -5.6 & -0.9 & -3.4 & -5.7 & -6.8 \\
\hline \multicolumn{9}{|c|}{$2009-2011$} \\
\hline \multirow{3}{*}{ Quintile: } & I & -26.5 & 3.7 & 2.1 & 1.5 & 2.3 & 10.7 & 6.1 \\
\hline & III & 0.0 & 0.7 & -0.6 & -1.3 & 0.8 & 0.7 & -0.4 \\
\hline & $\mathrm{V}$ & 25.4 & -3.1 & -11.0 & -3.0 & -3.6 & -0.2 & -4.6 \\
\hline \multicolumn{9}{|c|}{ 2011-2013 } \\
\hline \multirow{3}{*}{ Quintile: } & $\mathrm{I}$ & -22.9 & 3.4 & 6.4 & 3.0 & 2.3 & 1.5 & 6.2 \\
\hline & III & 0.3 & -0.2 & 0.8 & -0.4 & 0.9 & -0.2 & -1.3 \\
\hline & $\mathrm{V}$ & 25.6 & -4.1 & -6.1 & -2.0 & -3.3 & -3.3 & -6.8 \\
\hline \multicolumn{9}{|c|}{ MICRO AND SMALL FIRMS } \\
\hline \multirow{3}{*}{\multicolumn{2}{|c|}{ Period }} & \multicolumn{7}{|c|}{ Variation (p.p.) of the Shares in Total Assets of: } \\
\hline & & & \multicolumn{3}{|c|}{ Asset Side (+) } & \multicolumn{3}{|c|}{ Liability Side (-) } \\
\hline & & $\begin{array}{c}\text { Net Trade } \\
\text { Credit }\end{array}$ & Stocks & Cash & $\begin{array}{l}\text { Fixed } \\
\text { Assets }\end{array}$ & $\begin{array}{l}\text { Fin. } \\
\text { Debt }\end{array}$ & $\begin{array}{l}\text { Oth. } \\
\text { Liab. }\end{array}$ & $\begin{array}{l}\text { Sh. } \\
\text { Funds }\end{array}$ \\
\hline \multicolumn{9}{|c|}{ 2007-2009 } \\
\hline \multirow{3}{*}{ Quintile: } & $\mathrm{I}$ & -25.1 & 3.6 & 8.6 & 3.4 & 1.4 & 3.2 & 4.9 \\
\hline & III & 0.7 & 0.1 & 0.2 & 0.3 & 1.2 & 0.0 & -2.6 \\
\hline & $\mathrm{V}$ & 28.4 & -3.7 & -8.7 & -2.3 & -2.6 & -5.1 & -6.1 \\
\hline \multicolumn{9}{|c|}{$2009-2011$} \\
\hline \multirow{3}{*}{ Quintile: } & I & -27.0 & 3.7 & 7.9 & 2.0 & 2.1 & 5.1 & 6.3 \\
\hline & III & 0.0 & 0.3 & 0.2 & -0.9 & 1.8 & -0.2 & -1.1 \\
\hline & $\mathrm{V}$ & 26.6 & -3.2 & -9.4 & -3.5 & -1.2 & -4.2 & -5.1 \\
\hline \multicolumn{9}{|c|}{$2011-2013$} \\
\hline \multirow{3}{*}{ Quintile: } & $\mathrm{I}$ & -24.9 & 3.7 & 8.4 & 2.7 & 1.4 & 1.6 & 7.1 \\
\hline & III & 0.4 & 0.2 & 0.4 & -0.4 & 1.4 & -0.7 & -1.3 \\
\hline & $\mathrm{V}$ & 26.8 & -3.3 & -7.9 & -2.9 & -1.7 & -5.2 & -5.8 \\
\hline
\end{tabular}

Source: our elaboration on Amadeus data.

The quintile classification is based on the variations of the ratio between net trade credit and total assets within each period. Data in the table represent the changes in percentage points of individual budget items, each represented as a share of Total Assets. Figures are obtained as simple averages at the firm level. As indicated in the first row, changes on the assets side of the budget are reported as increases (actual sign, +), while changes on the liability side of the budget are reported as decreases (reversed sign, -). In this way, the sum of the entries in each row is zero. 
sources of financing (other liabilities), on the one hand, and to accept lower levels of capital expenditure (fixed assets), on the other hand.

Finally, we analyze the impact of the change in NTCS on wages and employment. Results are summarized in Table $10 .^{23}$

Table 10: Impact of NTCS on Wages and Employment

\begin{tabular}{|c|c|c|c|c|}
\hline \multirow[t]{2}{*}{ Dependent Variable: } & \multicolumn{2}{|c|}{ Wages $_{t} /$ TangFixAss $_{t-1}$} & \multicolumn{2}{|c|}{$\ln \left(N_{t} / N_{t-1}\right)$} \\
\hline & (1) & (2) & (3) & (4) \\
\hline NTCS & $\begin{array}{c}-0.0008^{* * *} \\
{[0.0001]}\end{array}$ & $\begin{array}{c}-0.0020^{* * *} \\
{[0.0001]}\end{array}$ & $\begin{array}{c}-0.0001^{* * *} \\
{[0.0000]}\end{array}$ & $\begin{array}{c}-0.0001^{* * *} \\
{[0.0000]}\end{array}$ \\
\hline Sales growth & $\begin{array}{l}0.0235^{\text {*** }} \\
{[0.0009]}\end{array}$ & $\begin{array}{l}0.0205^{* * *} \\
{[0.0009]}\end{array}$ & $\begin{array}{l}0.0011^{* * *} \\
{[0.0000]}\end{array}$ & $\begin{array}{c}0.0011^{* * *} \\
{[0.0000]}\end{array}$ \\
\hline Cash flow & $\begin{array}{l}1.2413^{* * *} \\
{[0.0046]}\end{array}$ & $\begin{array}{l}1.2520^{* * *} \\
{[0.0050]}\end{array}$ & $\begin{array}{l}0.0001^{* * *} \\
{[0.0000]}\end{array}$ & $\begin{array}{c}-0.0002^{* * *} \\
{[0.0001]}\end{array}$ \\
\hline Cash (lag) & & $\begin{array}{l}0.3594^{* * *} \\
{[0.0931]}\end{array}$ & & $\begin{array}{l}0.0535^{* * *} \\
{[0.0024]}\end{array}$ \\
\hline Tangibility (lag) & & $\begin{array}{c}-26.2570^{* * *} \\
{[0.0807]}\end{array}$ & & $\begin{array}{l}0.0290^{* * *} \\
{[0.0026]}\end{array}$ \\
\hline Profitability (lag) & & $\begin{array}{c}5.3809^{* * *} \\
{[0.1604]}\end{array}$ & & $\begin{array}{l}0.1535^{* * *} \\
{[0.0046]}\end{array}$ \\
\hline Cfw (lag) & & $\begin{array}{c}-12.7595^{* * *} \\
{[0.1894]}\end{array}$ & & $\begin{array}{c}0.0005 \\
{[0.0053]}\end{array}$ \\
\hline Leverage (lag) & & $\begin{array}{c}-3.8609^{* * *} \\
{[0.0579]}\end{array}$ & & $\begin{array}{c}-0.0359^{* * *} \\
{[0.0021]}\end{array}$ \\
\hline Firm F.E. & YES & YES & YES & YES \\
\hline Period F.E. & YES & YES & YES & YES \\
\hline Country-Period F.E. & YES & YES & YES & YES \\
\hline Industry-Period F.E. & YES & YES & YES & YES \\
\hline $\mathrm{N}$ & $5,914,200$ & $5,617,437$ & $3,587,874$ & $3,401,382$ \\
\hline $\mathrm{r} 2$ & 0.71 & 0.72 & 0.28 & 0.29 \\
\hline
\end{tabular}

Because of obvious endogeneity problems, our analysis provides correlations and cannot identify causal effects. Nevertheless, the analysis sheds light on the association between liquidity squeeze from NTCS and lower wages/employment. As expected, an increase in NTCS is negatively associated with both wages (the wage bill) and employment. Coefficients in both estimations appear low, but they are economically relevant. An increase by 10 days of NTCS is associated with a reduction by 2 percentage points in the ratio of the wage bill to fixed tangible

\footnotetext{
${ }^{23}$ Regressions with the Investment Ratio as the dependent variable, available upon request from the authors, yield similar results.
} 
assets. Given that we measure the wage bill in terms of fixed tangible assets, the negative impact of the increase in NTCS on the wage bill suggests that labor may be particularly vulnerable to the liquidity squeeze. Looking at the adjustment in employment, the estimated coefficient indicates that an increase in 10 days in NTCS is associated with a reduction by 0.1 percent in employment. Given the large degree of heterogeneity across firms, it is worth computing the impact of the standard deviation on both the wage bill and employment. An increase of one standard deviation in NTCS produces a reduction of 12 percentage points in the wage bill and of 0.6 percent in employment, indicating that the effects of increasing net trade credit on wages and employment are quantitatively relevant.

In sum, the liquidity squeeze induced by the increase in NTCS produces adverse effects on aggregate demand and on the real adjustment of firms, both on investments and on wages/employment. Given that SMEs are those that suffered the largest increase in NTCS, these results suggest that through the trade credit channel SMEs suffered a significant squeeze in their liquidity, which led to negative effects on their real activity.

\section{Concluding remarks}

In this paper, we have shown that in a period of financial crisis, trade credit is a relevant source of heterogeneity of effects on liquidity of firms characterized by different market power, financial characteristics and technologies. In particular, the evidence indicates that European SMEs have been squeezed in their liquidity during the Great Recession through an increase in their net trade credit. The evidence suggests that SMEs suffered because of their limited bargaining power in their credit relationship with larger firms. Financial characteristics of firms are also a significant determinant of net trade credit, suggesting that firms with ex ante higher availability of liquid assets or higher ability to generate cash flow tend to redistribute liquidity to other firms in the aftermath of the financial crisis. However, these financial conditions do not dominate the effect of firm size, as SMEs tend to provide more trade credit even after controlling for financial characteristics. The presence of a bias against SMEs liquidity due to weaker bargaining power is suggested by the analysis of the differential size of customer/suppliers. Firms concentrating their sales (purchases) to (from) sectors with higher concentration tend to supply more net trade credit during the crisis. Such relative bargaining power effect is highly significant, whereas technological aspects, such as the degree of upstreamness of production do not play a significant role during the crisis. 
In addition, the average net trade credit ratio tends to be higher in countries where the recession is more severe (and the recovery slower), showing a significant relationship with the business cycle (proxied by real GDP growth) rather than the financial cycle (proxied by changes in the growth rate of bank credit to GDP). This is likely attributable to the difficulties of final customers (households and governments) who impose greater payment delays in countries where the real economy suffers a deeper recession. The existence of country effects suggests that payment delays do not affect only downstream companies, but to some extent they also propagate along the production chain.

This does not imply that the financial cycle is irrelevant for the development of net trade credit. In fact, significant period-dummy effects suggest that the financial crisis had a relevant impact on the net trade credit ratio irrespective of the differential impact of GDP growth at the country level. In addition, the significant coefficients on the interaction between firms' characteristics and period dummies also reveal that the period of financial turmoil had a relevant impact not only on the levels but also on the heterogeneity of net trade credit among firms.

Our analysis shows as well that the dynamics of net trade credit played a quantitatively large effect on real performance, both on labor market variables and on investments. Therefore, the additional liquidity squeeze induced by changes in net trade credit positions determined long run negative effects on firms. Given that SMEs displayed the largest increase in their net trade credit positions, they also suffered most in terms of investments. A particularly worrying phenomenon is that the liquidity squeeze on SMEs has been a persistent phenomenon, lingering at least 5 years (our sample ends in 2013) after the start of the financial crisis.

This analysis may have relevant policy implications as it sheds light on the peculiar vulnerabilities of SMEs that can arise during financial crises through the channel of trade credit.

Policy makers have been aware of these problems and have tried to implement penalties for firms delaying their payments over 60 days. ${ }^{24}$

However, punitive measures are unlikely to go at the heart of the problem, as trade credit is tied with real transactions that cannot easily be replaced by firms. An implication of weak bargaining power by SMEs is that it is unlikely they will

\footnotetext{
${ }^{24}$ For instance, the Directive 2011/7/EU of the European Parliament and of the Council of 16 February 2011 on combating late payment in commercial transactions, as well as the Law on the Modernization of the Economy has had in France since 2008, are meant to reduce delays in payments among firms, introducing interest payments on overdue payments (longer than 60 days) and fixed penalties. Member States were suppose to implement such regulations by 16 March 2013.
} 
resort to legal actions with respect to the large customers for their inputs. Perhaps, such punitive actions may be relevant for trade debts of public administrations.

More effective policies may act on the possibility for SMEs to use their receivables as collateral for credit lines. Similarly, a much more efficient and widespread use of factoring, together with an expansion of the market for trade credit insurance may lead to substantial positive effects. Furthermore, securitisation of trade receivables by pooling the positions of several SMEs could be introduced.

Designing policy actions to tackle corporate finance issues for SMEs may be essential in positively influencing employment and investment decisions of SMEs in the aftermath of a crisis. Indeed, policies that reduce financial constraints on SMEs constitute an essential instrument for reallocating resources towards better performing firms. The rationale for these policies is not that SMEs deserve subsidies in normal times, but that policy intervention is needed to shield SMEs from an inefficient squeeze in their liquidity. 


\section{References}

Altman, Edward I, and Edith Hotchkiss. 2005. Corporate Financial Distress and Bankruptcy. Vol. 289, John Wiley \& Sons.

Altman, Edward I, and Gabriele Sabato. 2007. "Modelling credit risk for SMEs: Evidence from the US market." Abacus, 43(3): 332-357.

Angrist, Joshua D, and Jörn-Steffen Pischke. 2008. Mostly harmless econometrics: An empiricist's companion. Princeton university press.

Antras, Pol, Davin Chor, Thibault Fally, and Russell Hillberry. 2012. "Measuring the Upstreamness of Production and Trade Flows." American Economic Review, 102(3): 412-16.

Berger, Allen N, and Gregory F Udell. 1998. "The economics of small business finance: The roles of private equity and debt markets in the financial growth cycle." Journal of Banking \& Finance, 22(6): 613-673.

Biais, Bruno, and Christian Gollier. 1997. "Trade credit and credit rationing." Review of financial studies, 10(4): 903-937.

Boissay, Frederic, and Reint Gropp. 2013. "Payment Defaults and Interfirm Liquidity Provision.” Review of Finance, 17(6): 1853-1894.

Brechling, F. P. R., and R. G. Lipsey. 1963. "Trade Credit and Monetary Policy." The Economic Journal, 73(292): 618-641.

Brennan, Michael J, Vojislav Maksimovics, and Josef Zechner. 1988. "Vendor financing." The Journal of Finance, 43(5): 1127-1141.

Calvo, Guillermo A, and Fabrizio Coricelli. 1996. "Monetary policy and interenterprise arrears in post-communist economies: Theory and evidence." The Journal of Policy Reform, 1(1): 3-24.

Carbo-Valverde, Santiago, Francisco Rodriguez-Fernandez, and Gregory $\mathbf{F}$ Udell. 2013. "Trade Credit, the Financial Crisis, and SME Access to Finance." In 26th Australasian Finance and Banking Conference.

Coricelli, Fabrizio, and Marco Frigerio. 2015. "The Credit-Output Relationship During the Recovery from Recession." Open Economies Review, 26(3): 551579. 
Cunat, Vicente. 2007. "Trade credit: suppliers as debt collectors and insurance providers." Review of Financial Studies, 20(2): 491-527.

Ferris, J Stephen. 1981. “A transactions theory of trade credit use.” The Quarterly Journal of Economics, 243-270.

Gertler, Mark, and Simon Gilchrist. 1994. "Monetary Policy, Business Cycles, and the Behavior of Small Manufacturing Firms." The Quarterly Journal of Economics, 109(2): 309-340.

Giannetti, Mariassunta, Mike Burkart, and Tore Ellingsen. 2011. "What you sell is what you lend? Explaining trade credit contracts." Review of Financial Studies, 24(4): 1261-1298.

Giovannini, Alberto, Colin Mayer, Stefano Micossi, Carmine Di Noia, Marco Onado, Marco Pagano, and Andrea Polo. 2015. "Restarting European LongTerm Investment Finance." Green Paper Discussion Document, Centre for Economic Policy Research (CEPR).

Kalemli-Ozcan, Sebnem, Se-Jik Kim, Hyun Song Shin, Bent E Sørensen, and Sevcan Yesiltas. 2014. "Financial shocks in production chains." In American Economic Association meetings, January.

Kim, Se-Jik, and Hyun Song Shin. 2012. "Sustaining Production Chains through Financial Linkages." American Economic Review, 102(3): 402-06.

Kiyotaki, N, and J Moore. 2001. "Credit chains." Mimeo. Clarendon Lectures, University of Oxford, UK.

Klapper, Leora, Luc Laeven, and Raghuram Rajan. 2006. "Entry regulation as a barrier to entrepreneurship." Journal of Financial Economics, 82(3): 591629.

Love, Inessa, and Rida Zaidi. 2010. "Trade Credit, Bank Credit and Financial Crisis.” International Review of Finance, 10(1): 125-147.

Love, Inessa, Lorenzo A Preve, and Virginia Sarria-Allende. 2007. "Trade Credit and Bank Credit: Evidence from Recent Financial Crises." Journal of Financial Economics, 83(2): 453-469.

Meltzer, Allan H. 1960. "Mercantile credit, monetary policy, and size of firms." The Review of Economics and Statistics, 429-437. 
Mora, Jesse, and William Powers. 2009. "Did trade credit problems deepen the great trade collapse?" In The Great Trade Collapse: Causes, Consequences and Prospects., ed. R. Baldwin. CEPR.

Moulton, Brent R. 1986. "Random group effects and the precision of regression estimates." Journal of econometrics, 32(3): 385-397.

Nilsen, Jeffrey H. 2002. "Trade Credit and the Bank Lending Channel." Journal of Money, Credit, and Banking, 34(1): 226-253.

Norden, Lars, and Stefan van Kampen. 2015. “The Dynamics of Trade Credit and Bank Debt in SME Finance: International Evidence." In RBA Annual Conference Volume. Reserve Bank of Australia.

Petersen, Mitchell A, and Raghuram G Rajan. 1997. "Trade credit: theories and evidence." Review of financial studies, 10(3): 661-691.

Radcliffe Report. 1959. "Report of the Committee on the Working of the Monetary System.” London.

Raddatz, Claudio. 2010. "Credit chains and sectoral comovement: does the use of trade credit amplify sectoral shocks?" The Review of Economics and Statistics, 92(4): 985-1003.

Ramey, Valerie A. 1992. "The source of fluctuations in money: Evidence from trade credit." Journal of Monetary Economics, 30(2): 171-193.

Schwartz, Robert A. 1974. "An economic model of trade credit." Journal of financial and quantitative analysis, 9(04): 643-657.

Thomas, William Arthur. 1978. The Finance of British Industry, 1918-1976. Routledge.

Wilner, Benjamin S. 2000. "The exploitation of relationships in financial distress: The case of trade credit." The Journal of Finance, 55(1): 153-178. 


\section{Appendix}

\section{A Additional regressions}

\section{A.1 Robustness test to firms' independence}

Table 11: Heterogeneous firm responses - Independence class: A

\begin{tabular}{|c|c|c|c|c|}
\hline \multicolumn{5}{|l|}{ Dependent Variable: NTCS } \\
\hline & (1) & (2) & (3) & (4) \\
\hline Y2008-2011*Small & $\begin{array}{c}-2.40^{* * *} \\
{[0.69]}\end{array}$ & $\begin{array}{c}-2.06 * * * \\
{[0.69]}\end{array}$ & & \\
\hline Y2008-2011*Medium & $\begin{array}{c}-8.84^{* * *} \\
{[1.00]}\end{array}$ & $\begin{array}{l}-8.31^{* * *} \\
{[1.00]}\end{array}$ & & \\
\hline Y2008-2011*Large & $\begin{array}{c}-10.54^{* * *} \\
{[1.40]}\end{array}$ & $\begin{array}{c}-10.61 * * * \\
{[1.38]}\end{array}$ & & \\
\hline Y2012-2013*Small & $\begin{array}{c}-7.01^{* * *} \\
{[0.87]}\end{array}$ & $\begin{array}{c}-6.74^{* * *} \\
{[0.88]}\end{array}$ & & \\
\hline Y2012-2013*Medium & $\begin{array}{c}-17.56^{* * *} \\
{[1.24]}\end{array}$ & $\begin{array}{c}-17.77^{* * *} \\
{[1.24]}\end{array}$ & & \\
\hline Y2012-2013*Large & $\begin{array}{c}-20.09^{* * *} \\
{[1.72]}\end{array}$ & $\begin{array}{c}-19.86^{* * *} \\
{[1.69]}\end{array}$ & & \\
\hline Cfw (lag) & & $\begin{array}{c}25.34^{* * *} \\
{[4.72]}\end{array}$ & & $\begin{array}{l}25.23 * * * \\
{[4.72]}\end{array}$ \\
\hline Y2005-2007*Cfw(lag) & & & $\begin{array}{l}16.40^{* * *} \\
{[5.21]}\end{array}$ & \\
\hline Y2008-2011*Cfw(lag) & & & $\begin{array}{l}24.60^{* * *} \\
{[4.98]}\end{array}$ & \\
\hline Y2012-2013*Cfw(lag) & & & $\begin{array}{l}39.97 * * * \\
{[5.73]}\end{array}$ & \\
\hline Leverage (lag) & & $\begin{array}{l}13.92^{* * *} \\
{[1.59]}\end{array}$ & $\begin{array}{l}14.09^{* * *} \\
{[1.60]}\end{array}$ & \\
\hline Y2005-2007*Leverage(lag) & & & & $\begin{array}{l}21.12^{* * *} \\
{[2.03]}\end{array}$ \\
\hline Y2008-2011*Leverage(lag) & & & & $\begin{array}{l}14.24^{* * *} \\
{[1.81]}\end{array}$ \\
\hline Y2012-2013*Leverage(lag) & & & & $\begin{array}{l}2.12 \\
{[2.27]}\end{array}$ \\
\hline Cash (lag) & & $\begin{array}{c}-18.10^{* * *} \\
{[1.71]}\end{array}$ & $\begin{array}{c}-18.26^{* * *} \\
{[1.71]}\end{array}$ & $\begin{array}{c}-18.27^{* * *} \\
{[1.71]}\end{array}$ \\
\hline Tangibility (lag) & & $-28.44^{* * *}$ & $-28.84^{* * *}$ & $\begin{array}{l}-28.58^{* * *} \\
{[2.24}\end{array}$ \\
\hline Profitability (lag) & & $\begin{array}{c}{[2.23]} \\
-8.58 * * \\
{[3.82]}\end{array}$ & $\begin{array}{c}{[2.23]} \\
-8.85^{* *} \\
{[3.82]}\end{array}$ & $\begin{array}{c}{\left[-8.26^{* *}\right.} \\
{[3.82]}\end{array}$ \\
\hline Firm F.E. & YES & YES & YES & YES \\
\hline Period F.E. & YES & YES & YES & YES \\
\hline Country-Period F.E. & YES & YES & YES & YES \\
\hline Industry-Period F.E. & YES & YES & YES & YES \\
\hline $\mathrm{N}$ & 278,480 & 261,718 & 261,718 & 261,718 \\
\hline $\mathrm{r} 2$ & 0.71 & 0.72 & 0.72 & 0.72 \\
\hline
\end{tabular}




\section{A.2 Robustness test to firms' access to finance}

The estimated model of Table 12 replicates the one estimated in Column 1 and Column 2 of Table 4 two specific sub-groups of firms, i.e. Constrained vs. Unconstrained firms. The inclusion/exclusion of individual firms in the two subsamples is based on their estimated credit quality. Credit quality is proxied by the renowned measure Z"-Score (Altman and Hotchkiss, 2005), that is modeled as follows:

$$
Z \text { 'Score }=6.56 \cdot X_{1}+3.26 \cdot X_{2}+6.72 \cdot X_{3}+1.05 \cdot X_{4}
$$

where:

$$
\begin{aligned}
& X_{1}=\text { Working Capital/Total Assets } \\
& X_{2}=\text { Retained Earnings } / \text { Total Assets } \\
& X_{3}=\text { EBIT } / \text { Total Assets, } \\
& X_{4}=\text { Book Value Equity/Total Assets } .
\end{aligned}
$$

Retained Earnings are not available in the Amadeus dataset, and thus in our measure of Z"-Score they are proxied by the simple difference between Shareholders' Funds and Capital.

Such Z"-Score models are usually estimated on the US and on samples dominated by listed companies. This could make the models less suitable for evaluating small firms. In order to take into account the limits of applying a single model for firms of different size, we adopt the following procedure. We regress the measured Z"-Score on a series of dummies that identify the different industries (NACE Rev.2, 3-digit), the size (micro, small, medium, large) and the countryyear pairs. We then split the sample into quartiles based on the residuals of the regression. For each firm, we take the median quartile across the whole period of our estimation.

With this procedure, we are able to classify firms on a relative basis, since their financial health is evaluated with respect to the estimated averages of the corresponding cluster (industry, size, country-year). This makes our classification less dependent on the specific model adopted. ${ }^{25}$

The subsamples of Constrained and Unconstrained firms coincide respectively with the I and IV quartiles resulting from the procedure just described.

\footnotetext{
${ }^{25}$ Indeed, we verified that the quartile subdivision of the available observations does not significantly change across different models, such the one developed in Altman and Sabato (2007) to consider the specificities of the SME sector.
} 
Table 12 shows that the main results of the paper do not change even after splitting the sample on the basis of this classification. However, the differentials across size classes are higher among the unconstrained firms. In unreported regressions, available on request, we also repeated the estimations of Table 6 by using Receivables to Sales and Payables to Sales as the dependent variables.

Table 12: Heterogeneous firm responses - Constrained vs. Unconstrained

\begin{tabular}{|c|c|c|c|c|}
\hline \multicolumn{5}{|c|}{ Dependent Variable: NTCS } \\
\hline & \multicolumn{2}{|c|}{ Constrained } & \multicolumn{2}{|c|}{ Unconstrained } \\
\hline & (1) & (2) & (3) & (4) \\
\hline Y2008-2011*Small & $\begin{array}{c}-2.19^{* * *} \\
{[0.43]}\end{array}$ & $\begin{array}{l}-2.08^{* * *} \\
{[0.43]}\end{array}$ & $\begin{array}{c}-3.04^{* * *} \\
{[0.28]}\end{array}$ & $\begin{array}{c}-2.86^{* *} \\
{[0.28]}\end{array}$ \\
\hline Y2008-2011*Medium & $\begin{array}{c}-5.13^{* * *} \\
{[0.74]}\end{array}$ & $\begin{array}{c}-4.80^{* * *} \\
{[0.74]}\end{array}$ & $\begin{array}{c}-9.51^{* * *} \\
{[0.46]}\end{array}$ & $\begin{array}{c}-9.35^{* *} \\
{[0.46]}\end{array}$ \\
\hline Y2008-2011*Large & $\begin{array}{c}-5.83^{* * *} \\
{[1.06]}\end{array}$ & $\begin{array}{c}-5.24^{* * *} \\
{[1.08]}\end{array}$ & $\begin{array}{c}-11.76^{* * *} \\
{[0.70]}\end{array}$ & $\begin{array}{c}-11.78^{* *} \\
{[0.70]}\end{array}$ \\
\hline Y2012-2013*Small & $\begin{array}{c}-4.85^{* * *} \\
{[0.56]}\end{array}$ & $\begin{array}{c}-4.92^{* * *} \\
{[0.57]}\end{array}$ & $\begin{array}{c}-5.36^{* * *} \\
{[0.37]}\end{array}$ & $\begin{array}{c}-5.08^{* *} \\
{[0.37]}\end{array}$ \\
\hline Y2012-2013*Medium & $\begin{array}{c}-10.22^{* * *} \\
{[0.98]}\end{array}$ & $\begin{array}{c}-10.41^{* * *} \\
{[1.00]}\end{array}$ & $\begin{array}{c}-16.80^{* * *} \\
{[0.59]}\end{array}$ & $\begin{array}{c}-16.56^{* *} \\
{[0.60]}\end{array}$ \\
\hline Y2012-2013*Large & $\begin{array}{c}-11.63^{* * *} \\
{[1.33]}\end{array}$ & $\begin{array}{c}-11.99^{* * *} \\
{[1.36]}\end{array}$ & $\begin{array}{c}-19.73^{* * *} \\
{[0.90]}\end{array}$ & $\begin{array}{c}-19.59^{* *} \\
{[0.90]}\end{array}$ \\
\hline Cfw (lag) & & $\begin{array}{l}22.39^{* * *} \\
{[1.76]}\end{array}$ & & $\begin{array}{l}9.30^{* *} \\
{[1.60]}\end{array}$ \\
\hline Leverage (lag) & & $\begin{array}{l}14.55^{* * *} \\
{[0.67]}\end{array}$ & & $\begin{array}{l}2.12^{* *} \\
{[0.87]}\end{array}$ \\
\hline Cash (lag) & & $\begin{array}{c}-7.03^{* * *} \\
{[0.99]}\end{array}$ & & $\begin{array}{c}-16.83^{* *} \\
{[0.53}\end{array}$ \\
\hline Tangibility (lag) & & $\begin{array}{c}-26.30^{* * * *} \\
{[1.01]}\end{array}$ & & $\begin{array}{c}-32.05^{* *} \\
{[0.95]}\end{array}$ \\
\hline Profitability (lag) & & $\begin{array}{c}0.63 \\
{[1.54]}\end{array}$ & & $\begin{array}{c}-11.01^{* *} \\
{[1.29]}\end{array}$ \\
\hline Firm F.E. & YES & YES & YES & YES \\
\hline Period F.E. & YES & YES & YES & YES \\
\hline Country-Period F.E. & YES & YES & YES & YES \\
\hline Industry-Period F.E. & YES & YES & YES & YES \\
\hline $\mathrm{N}$ & $1,181,958$ & $1,078,164$ & $1,630,155$ & $1,494,563$ \\
\hline $\mathrm{r} 2$ & 0.70 & 0.71 & 0.72 & 0.73 \\
\hline
\end{tabular}




\section{A.3 Additional regressions for receivables and payables}

Table 13: Receivables, payables and sales: regressions by country (year 2007)

\begin{tabular}{|c|c|c|c|c|}
\hline \multicolumn{5}{|c|}{ Dependent variable: log receivables } \\
\hline Year & log payables & log sales & Obs. & $R^{2}$ \\
\hline Austria & 0.07 & 0.94 & 1,065 & 0.62 \\
\hline Iceland & 0.07 & 0.79 & 1,163 & 0.58 \\
\hline Germany & 0.10 & 0.90 & 12,253 & 0.74 \\
\hline Finland & 0.16 & 0.80 & 46,844 & 0.68 \\
\hline Luxembourg & 0.16 & 0.72 & 255 & 0.66 \\
\hline Estonia & 0.17 & 0.76 & 22,596 & 0.64 \\
\hline Norway & 0.20 & 0.71 & 62,090 & 0.60 \\
\hline France & 0.22 & 0.72 & 305,698 & 0.51 \\
\hline Portugal & 0.23 & 0.70 & 113,969 & 0.60 \\
\hline Latvia & 0.23 & 0.76 & 4,769 & 0.65 \\
\hline Lithuania & 0.24 & 0.72 & 1,329 & 0.62 \\
\hline Slovakia & 0.26 & 0.73 & 5,935 & 0.79 \\
\hline Hungary & 0.27 & 0.66 & 6,018 & 0.69 \\
\hline Switzerland & 0.28 & 0.82 & 191 & 0.73 \\
\hline Sweden & 0.29 & 0.78 & 7,820 & 0.54 \\
\hline Czech Republic & 0.30 & 0.66 & 21,351 & 0.78 \\
\hline Italy & 0.30 & 0.63 & 324,143 & 0.65 \\
\hline Poland & 0.31 & 0.64 & 26,583 & 0.79 \\
\hline Croatia & 0.31 & 0.61 & 41,236 & 0.71 \\
\hline Greece & 0.31 & 0.68 & 14,775 & 0.66 \\
\hline Bulgaria & 0.32 & 0.68 & 16,340 & 0.55 \\
\hline Bosnia & 0.35 & 0.62 & 8,178 & 0.71 \\
\hline Spain & 0.36 & 0.62 & 17,214 & 0.67 \\
\hline Belgium & 0.36 & 0.58 & 10,985 & 0.74 \\
\hline Ukraine & 0.40 & 0.53 & 59,191 & 0.65 \\
\hline Russia & 0.49 & 0.49 & 24 & 0.90 \\
\hline Slovenia & 0.50 & 0.49 & 6,519 & 0.84 \\
\hline
\end{tabular}

Cross-section OLS regression results from a balanced AMADEUS sample, after removing firms that did not report a positive figure for either receivables or payables. This table reports country-specific OLS coefficients estimated in the pre-crisis year 2007. 


\section{Table 14: Heterogeneous responses by industry - Receivables}

\begin{tabular}{|c|c|c|c|c|}
\hline & \multicolumn{2}{|c|}{ 2008-2011 vs. precrisis } & \multicolumn{2}{|c|}{ 2012-2013 vs. precrisis } \\
\hline & (1) & (2) & (3) & (4) \\
\hline RelativeSize & $\begin{array}{c}-6.66^{* * *} \\
{[2.39]}\end{array}$ & $\begin{array}{c}-5.90^{* * *} \\
{[2.21]}\end{array}$ & $\begin{array}{c}-14.27^{* * *} \\
{[4.34]}\end{array}$ & $\begin{array}{c}-13.21^{* * *} \\
{[4.36]}\end{array}$ \\
\hline Weight_Households_Customers & $\begin{array}{c}-7.62^{* * *} \\
{[1.88]}\end{array}$ & $\begin{array}{c}-8.60^{* * *} \\
{[2.13]}\end{array}$ & $\begin{array}{c}-20.25^{* * *} \\
{[3.45]}\end{array}$ & $\begin{array}{c}-20.14^{* * *} \\
{[4.31]}\end{array}$ \\
\hline Leverage_Customers & $\begin{array}{c}-88.68^{* * *} \\
{[20.13]}\end{array}$ & $\begin{array}{c}-93.15^{* * *} \\
{[21.32]}\end{array}$ & $\begin{array}{c}-215.85^{* * *} \\
{[35.62]}\end{array}$ & $\begin{array}{c}-215.04^{* * *} \\
{[40.37]}\end{array}$ \\
\hline Weight_Agriculture_Customers & & $\begin{array}{c}0.58 \\
{[7.98]}\end{array}$ & & $\begin{array}{r}-18.31^{*} \\
{[9.47]}\end{array}$ \\
\hline Weight_Financial_Customers & & $\begin{array}{c}37.28^{*} \\
{[19.82]}\end{array}$ & & $\begin{array}{c}60.62^{*} \\
{[33.46]}\end{array}$ \\
\hline Weight_Other_Customers & & $\begin{array}{c}-12.13^{* *} \\
{[5.87]}\end{array}$ & & $\begin{array}{c}-8.43 \\
{[9.83]}\end{array}$ \\
\hline _cons & $\begin{array}{l}18.61^{* * *} \\
{[1.38]}\end{array}$ & $\begin{array}{l}19.71^{* * *} \\
{[1.85]}\end{array}$ & $\begin{array}{l}38.23^{* * *} \\
{[2.79]}\end{array}$ & $\begin{array}{l}38.13^{* * *} \\
{[3.97]}\end{array}$ \\
\hline $\mathrm{N}$ & 198 & 198 & 198 & 198 \\
\hline r2 & 0.18 & 0.20 & 0.26 & 0.28 \\
\hline
\end{tabular}

${ }^{* * *} p<0.01,{ }^{* *} p<0.05,{ }^{*} p<0.1$ 
Table 15: Heterogeneous responses by industry - Payables

\begin{tabular}{|c|c|c|c|c|}
\hline & \multicolumn{2}{|c|}{ 2008-2011 vs. precrisis } & \multicolumn{2}{|c|}{ 2012-2013 vs. precrisis } \\
\hline & (1) & (2) & (3) & (4) \\
\hline RelativeSize & $\begin{array}{c}0.60 \\
{[2.39]}\end{array}$ & $\begin{array}{c}-0.15 \\
{[2.47]}\end{array}$ & $\begin{array}{c}4.37 \\
{[3.12]}\end{array}$ & $\begin{array}{c}2.29 \\
{[3.07]}\end{array}$ \\
\hline Weight_Households_Customers & $\begin{array}{l}2.30^{* *} \\
{[1.01]}\end{array}$ & $\begin{array}{c}1.60 \\
{[1.05]}\end{array}$ & $\begin{array}{l}4.03^{* * *} \\
{[1.43]}\end{array}$ & $\begin{array}{l}3.42^{* *} \\
{[1.39]}\end{array}$ \\
\hline Leverage_Suppliers & $\begin{array}{l}-3.96 \\
{[14.23]}\end{array}$ & $\begin{array}{c}12.76 \\
{[25.30]}\end{array}$ & $\begin{array}{c}5.19 \\
{[20.45]}\end{array}$ & $\begin{array}{c}2.77 \\
{[33.78]}\end{array}$ \\
\hline Weight_Agriculture_Suppliers & & $\begin{array}{c}9.55^{* *} \\
{[4.00]}\end{array}$ & & $\begin{array}{c}8.40 \\
{[5.18]}\end{array}$ \\
\hline Weight_Financial_Suppliers & & $\begin{array}{c}0.61 \\
{[15.45]}\end{array}$ & & $\begin{array}{c}-19.92 \\
{[15.98]}\end{array}$ \\
\hline Weight_Other_Suppliers & & $\begin{array}{c}16.78 \\
{[16.94]}\end{array}$ & & $\begin{array}{c}23.08 \\
{[23.13]}\end{array}$ \\
\hline _cons & $\begin{array}{r}-1.74 \\
{[1.17]}\end{array}$ & $\begin{array}{c}-3.51 \\
{[2.96]}\end{array}$ & $\begin{array}{c}-4.66^{* * *} \\
{[1.69]}\end{array}$ & $\begin{array}{c}-3.91 \\
{[3.83]}\end{array}$ \\
\hline $\mathrm{N}$ & 198 & 198 & 198 & 198 \\
\hline r2 & 0.02 & 0.05 & 0.07 & 0.11 \\
\hline
\end{tabular}

Robust standard errors in brackets. 


\section{B Rankings across industries at 3-digit level}

\section{B.1 Pre-crisis $N T C S$}

Table 16: NTCS across European industries in pre-crisis years [1 of 3]

\begin{tabular}{|c|c|}
\hline Industry [NACE Code] & Precrisis NTCS \\
\hline Retail Sale of Cultural and Recreation Goods in Specialized Stores [47.6] & -31.5 \\
\hline Sale, Maintenance and Repair of Motorcycles and Related Parts and Accessories [45.4] & -26.7 \\
\hline Retail Sale of Other Goods in Specialized Stores [47.7] & -24.8 \\
\hline Retail Sale of Other Household Equipment in Specialized Stores [47.5] & -21.4 \\
\hline Retail Sale in Non-Specialized Stores [47.1] & -20.3 \\
\hline Retail Sale of Food, Beverages and Tobacco in Specialized Stores [47.2] & -14.9 \\
\hline Camping Grounds, Recreational Vehicle Parks and Trailer Parks [55.3] & -13.0 \\
\hline Retail Sale Via Stalls and Markets [47.8] & -12.6 \\
\hline Restaurants and Mobile Food Service Activities [56.1] & -12.5 \\
\hline Retail Trade Not in Stores, Stalls Or Markets [47.9] & -10.2 \\
\hline Hotels and Similar Accommodation [55.1] & -9.4 \\
\hline Beverage Serving Activities [56.3] & -8.8 \\
\hline Sale of Motor Vehicle Parts and Accessories [45.3] & -7.9 \\
\hline Sale of Motor Vehicles [45.1] & -7.5 \\
\hline Passenger Rail Transport, Interurban [49.1] & -7.3 \\
\hline Manufacture of Bakery and Farinaceous Products [10.7] & -7.3 \\
\hline Retail Sale of Automotive Fuel in Specialized Stores [47.3] & -6.5 \\
\hline Holiday and Other Short-Stay Accommodation [55.2] & -6.2 \\
\hline Development of Building Projects [41.1] & -5.0 \\
\hline Inland Passenger Water Transport [50.3] & -4.3 \\
\hline Retail Sale of Information and Communication Equipment in Specialized Stores [47.4] & -3.8 \\
\hline Travel Agency and Tour Operator Activities [79.1] & -2.6 \\
\hline Photographic Activities [74.2] & -2.4 \\
\hline Sea and Coastal Passenger Water Transport [50.1] & -1.3 \\
\hline Buying and Selling of Own Real Estate [68.1] & -0.9 \\
\hline Other Accommodation [55.9] & -0.5 \\
\hline Veterinary Activities [75.0] & -0.3 \\
\hline Repair of Personal and Household Goods [95.2] & 0.1 \\
\hline Non-Specialized Wholesale Trade [46.9] & 0.9 \\
\hline Manufacture of Motor Vehicles [29.1] & 1.4 \\
\hline Maintenance and Repair of Motor Vehicles [45.2] & 2.3 \\
\hline Wholesale of Food, Beverages and Tobacco [46.3] & 2.5 \\
\hline Manufacture of Coke Oven Products [19.1] & 2.7 \\
\hline Renting and Leasing of Personal and Household Goods [77.2] & 2.9 \\
\hline Other Telecommunications Activities [61.9] & 3.5 \\
\hline Processing and Preserving of Meat and Production of Meat Products [10.1] & 3.9 \\
\hline Event Catering and Other Food Service Activities [56.2] & 4.2 \\
\hline Passenger Air Transport [51.1] & 4.2 \\
\hline Manufacture of Dairy Products [10.5] & 4.4 \\
\hline Renting and Operating of Own Or Leased Real Estate [68.2] & 4.9 \\
\hline Manufacture of Vegetable and Animal Oils and Fats [10.4] & 4.9 \\
\hline Freight Air Transport and Space Transport [51.2] & 6.4 \\
\hline Construction of Residential and Non-Residential Buildings [41.2] & 6.6 \\
\hline Manufacture of Articles of Fur [14.2] & 7.1 \\
\hline Processing and Preserving of Fruit and Vegetables [10.3] & 7.2 \\
\hline Manufacture of Transport Equipment N.E.C. [30.9] & 7.9 \\
\hline Other Specialized Wholesale [46.7] & 8.1 \\
\hline Wholesale of Agricultural Raw Materials and Live Animals [46.2] & 8.6 \\
\hline Wholesale of Household Goods [46.4] & 9.4 \\
\hline Combined Facilities Support Activities [81.1] & 9.7 \\
\hline Processing and Preserving of Fish, Crustaceans and Molluscs [10.2] & 10.1 \\
\hline Transport Via Pipeline [49.5] & 10.2 \\
\hline Manufacture of Other Food Products [10.8] & 10.3 \\
\hline Organization of Conventions and Trade Shows [82.3] & 10.4 \\
\hline
\end{tabular}




\section{NTCS across European industries in pre-crisis years [2 of 3]}

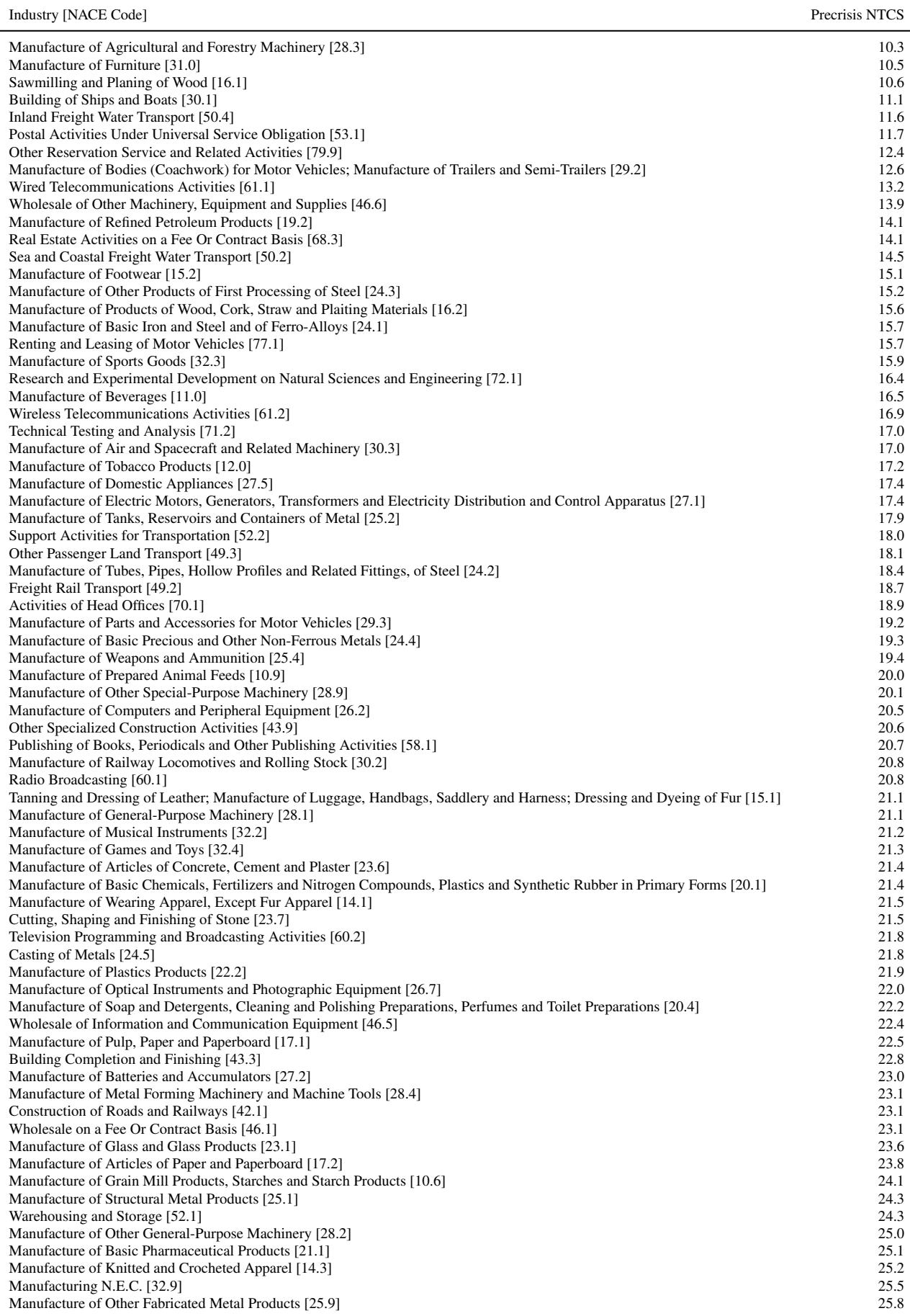




\section{NTCS across European industries in pre-crisis years [3 of 3]}

\begin{tabular}{|c|c|}
\hline Industry [NACE Code] & Precrisis NTCS \\
\hline Manufacture of Rubber Products [22.1] & 26.0 \\
\hline Manufacture of Other Textiles [13.9] & 26.0 \\
\hline Manufacture of Steam Generators, Except Central Heating Hot Water Boilers [25.3] & 26.1 \\
\hline Manufacture of Cement, Lime and Plaster [23.5] & 26.1 \\
\hline Sound Recording and Music Publishing Activities [59.2] & 26.5 \\
\hline Manufacture of Paints, Varnishes and Similar Coatings, Printing Ink and Mastics [20.3] & 26.6 \\
\hline Electrical, Plumbing and Other Construction Installation Activities [43.2] & 26.7 \\
\hline Repair of Computers and Communication Equipment [95.1] & 26.9 \\
\hline Manufacture of Medical and Dental Instruments and Supplies [32.5] & 27.0 \\
\hline Construction of Other Civil Engineering Projects [42.9] & 27.0 \\
\hline Motion Picture, Video and Television Programme Activities [59.1] & 27.1 \\
\hline Office Administrative and Support Activities [82.1] & 27.2 \\
\hline Manufacture of Electric Lighting Equipment [27.4] & 27.6 \\
\hline Satellite Telecommunications Activities [61.3] & 27.6 \\
\hline Manufacture of Man-Made Fibres [20.6] & 27.8 \\
\hline Manufacture of Clay Building Materials [23.3] & 27.8 \\
\hline Manufacture of Abrasive Products and Non-Metallic Mineral Products N.E.C. [23.9] & 28.2 \\
\hline Preparation and Spinning of Textile Fibres [13.1] & 28.3 \\
\hline Manufacture of Jewellery, Bijouterie and Related Articles [32.1] & 28.5 \\
\hline Manufacture of Other Chemical Products [20.5] & 28.6 \\
\hline Manufacture of Pharmaceutical Preparations [21.2] & 29.0 \\
\hline Forging, Pressing, Stamping and Roll-Forming of Metal; Powder Metallurgy [25.5] & 29.4 \\
\hline Renting and Leasing of Other Machinery, Equipment and Tangible Goods [77.3] & 29.7 \\
\hline Manufacture of Refractory Products [23.2] & 29.8 \\
\hline Advertising [73.1] & 30.1 \\
\hline Manufacture of Other Porcelain and Ceramic Products [23.4] & 30.5 \\
\hline Weaving of Textiles [13.2] & 30.7 \\
\hline Manufacture of Communication Equipment [26.3] & 30.7 \\
\hline Manufacture of Irradiation, Electromedical and Electrotherapeutic Equipment [26.6] & 30.7 \\
\hline Manufacture of Other Electrical Equipment [27.9] & 31.2 \\
\hline Manufacture of Consumer Electronics [26.4] & 31.5 \\
\hline Manufacture of Wiring and Wiring Devices [27.3] & 31.5 \\
\hline Manufacture of Pesticides and Other Agrochemical Products [20.2] & 31.5 \\
\hline Manufacture of Electronic Components and Boards [26.1] & 32.6 \\
\hline Construction of Utility Projects [42.2] & 32.6 \\
\hline Freight Transport By Road and Removal Services [49.4] & 33.0 \\
\hline Other Postal and Courier Activities [53.2] & 33.2 \\
\hline Landscape Service Activities [81.3] & 33.5 \\
\hline Demolition and Site Preparation [43.1] & 34.5 \\
\hline Printing and Service Activities Related to Printing [18.1] & 34.9 \\
\hline Manufacture of Instruments and Appliances for Measuring, Testing and Navigation; Watches and Clocks [26.5] & 34.9 \\
\hline Translation and Interpretation Activities [74.3] & 35.1 \\
\hline Repair of Fabricated Metal Products, Machinery and Equipment [33.1] & 35.2 \\
\hline Business Support Service Activities N.E.C. [82.9] & 35.4 \\
\hline Reproduction of Recorded Media [18.2] & 36.5 \\
\hline Specialized Design Activities [74.1] & 37.3 \\
\hline Security Systems Service Activities [80.2] & 37.5 \\
\hline Manufacture of Military Fighting Vehicles [30.4] & 38.8 \\
\hline Manufacture of Cutlery, Tools and General Hardware [25.7] & 38.8 \\
\hline Other Information Service Activities [63.9] & 39.6 \\
\hline Leasing of Intellectual Property and Similar Products, Except Copyrighted Works [77.4] & 39.8 \\
\hline Activities of Employment Placement Agencies [78.1] & 40.0 \\
\hline Private Security Activities [80.1] & 42.5 \\
\hline Manufacture of Magnetic and Optical Media [26.8] & 43.4 \\
\hline Treatment and Coating of Metals; Machining [25.6] & 43.4 \\
\hline Finishing of Textiles [13.3] & 43.4 \\
\hline Market Research and Public Opinion Polling [73.2] & 44.5 \\
\hline Other Human Resources Provision [78.3] & 45.3 \\
\hline Investigation Activities [80.3] & 45.3 \\
\hline Activities of Call Centres [82.2] & 45.5 \\
\hline Other Professional, Scientific and Technical Activities N.E.C. [74.9] & 46.5 \\
\hline Research and Experimental Development on Social Sciences and Humanities [72.2] & 46.8 \\
\hline Installation of Industrial Machinery and Equipment [33.2] & 47.9 \\
\hline Legal Activities [69.1] & 48.0 \\
\hline Management Consultancy Activities [70.2] & 48.2 \\
\hline Computer Programming, Consultancy and Related Activities [62.0] & 48.9 \\
\hline Software Publishing [58.2] & 52.8 \\
\hline Architectural and Engineering Activities and Related Technical Consultancy [71.1] & 52.8 \\
\hline Cleaning Activities [81.2] & 54.1 \\
\hline Temporary Employment Agency Activities [78.2] & 63.5 \\
\hline Data Processing, Hosting and Related Activities; Web Portals [63.1] & 66.3 \\
\hline Accounting, Bookkeeping and Auditing Activities; Tax Consultancy [69.2] & 68.1 \\
\hline
\end{tabular}




\section{B.2 Upstreamness}

Table 17: Upstreamness across NACE industries based on U.S. data [1 of 3]

\begin{tabular}{|c|c|}
\hline Industry [NACE Code] & Upstreamness \\
\hline Manufacture of Motor Vehicles [29.1] & 1.007 \\
\hline Manufacture of Footwear [15.2] & 1.008 \\
\hline Manufacture of Games and Toys [32.4] & 1.057 \\
\hline Manufacture of Sports Goods [32.3] & 1.057 \\
\hline Manufacture of Tobacco Products [12.0] & 1.066 \\
\hline Manufacture of Military Fighting Vehicles [30.4] & 1.070 \\
\hline Manufacture of Articles of Fur [14.2] & 1.115 \\
\hline Manufacture of Wearing Apparel, Except Fur Apparel [14.1] & 1.115 \\
\hline Retail Sale of Other Goods in Specialized Stores [47.7] & 1.126 \\
\hline Retail Sale of Other Household Equipment in Specialized Stores [47.5] & 1.126 \\
\hline Retail Trade Not in Stores, Stalls Or Markets [47.9] & 1.126 \\
\hline Retail Sale of Automotive Fuel in Specialized Stores [47.3] & 1.126 \\
\hline Retail Sale of Cultural and Recreation Goods in Specialized Stores [47.6] & 1.126 \\
\hline Retail Sale Via Stalls and Markets [47.8] & 1.126 \\
\hline Retail Sale of Food, Beverages and Tobacco in Specialized Stores [47.2] & 1.126 \\
\hline Retail Sale of Information and Communication Equipment in Specialized Stores [47.4] & 1.126 \\
\hline Retail Sale in Non-Specialized Stores [47.1] & 1.126 \\
\hline Manufacture of Consumer Electronics [26.4] & 1.135 \\
\hline Manufacture of Jewellery, Bijouterie and Related Articles [32.1] & 1.139 \\
\hline Manufacture of Musical Instruments [32.2] & 1.160 \\
\hline Manufacture of Irradiation, Electromedical and Electrotherapeutic Equipment [26.6] & 1.176 \\
\hline Manufacture of Domestic Appliances [27.5] & 1.181 \\
\hline Building of Ships and Boats [30.1] & 1.204 \\
\hline Manufacture of Beverages [11.0] & 1.214 \\
\hline Veterinary Activities [75.0] & 1.220 \\
\hline Manufacture of Optical Instruments and Photographic Equipment [26.7] & 1.225 \\
\hline Demolition and Site Preparation [43.1] & 1.238 \\
\hline Other Specialized Construction Activities [43.9] & 1.238 \\
\hline Development of Building Projects [41.1] & 1.238 \\
\hline Electrical, Plumbing and Other Construction Installation Activities [43.2] & 1.238 \\
\hline Construction of Roads and Railways [42.1] & 1.238 \\
\hline Construction of Residential and Non-Residential Buildings [41.2] & 1.238 \\
\hline Construction of Other Civil Engineering Projects [42.9] & 1.238 \\
\hline Construction of Utility Projects [42.2] & 1.238 \\
\hline Building Completion and Finishing [43.3] & 1.238 \\
\hline Manufacture of Transport Equipment N.E.C. [30.9] & 1.240 \\
\hline Software Publishing [58.2] & 1.265 \\
\hline Manufacture of Knitted and Crocheted Apparel [14.3] & 1.306 \\
\hline Manufacture of Bodies (Coachwork) for Motor Vehicles; Manufacture of Trailers and Semi-Trailers [29.2] & 1.306 \\
\hline Manufacture of Furniture [31.0] & 1.326 \\
\hline Manufacture of Other Electrical Equipment [27.9] & 1.344 \\
\hline Event Catering and Other Food Service Activities [56.2] & 1.389 \\
\hline Restaurants and Mobile Food Service Activities [56.1] & 1.389 \\
\hline Beverage Serving Activities [56.3] & 1.389 \\
\hline Manufacture of Soap and Detergents, Cleaning and Polishing Preparations, Perfumes and Toilet Preparations [20.4] & 1.399 \\
\hline Manufacture of Weapons and Ammunition [25.4] & 1.418 \\
\hline Maintenance and Repair of Motor Vehicles [45.2] & 1.438 \\
\hline Manufacture of Computers and Peripheral Equipment [26.2] & 1.441 \\
\hline Manufacture of Communication Equipment [26.3] & 1.445 \\
\hline Manufacture of Pharmaceutical Preparations [21.2] & 1.475 \\
\hline Renting and Leasing of Personal and Household Goods [77.2] & 1.483 \\
\hline Manufacture of Instruments and Appliances for Measuring, Testing and Navigation; Watches and Clocks [26.5] & 1.557 \\
\hline Manufacture of Medical and Dental Instruments and Supplies [32.5] & 1.562 \\
\hline Publishing of Books, Periodicals and Other Publishing Activities [58.1] & 1.569 \\
\hline
\end{tabular}




\section{Upstreamness across NACE industries based on U.S. data [2 of 3]}

\begin{tabular}{|c|c|}
\hline Industry [NACE Code] & Upstreamness \\
\hline Sound Recording and Music Publishing Activities [59.2] & 1.600 \\
\hline Manufacture of Dairy Products [10.5] & 1.610 \\
\hline Processing and Preserving of Fruit and Vegetables [10.3] & 1.610 \\
\hline Manufacture of Bakery and Farinaceous Products [10.7] & 1.610 \\
\hline Processing and Preserving of Meat and Production of Meat Products [10.1] & 1.610 \\
\hline Processing and Preserving of Fish, Crustaceans and Molluscs [10.2] & 1.610 \\
\hline Manufacture of Vegetable and Animal Oils and Fats [10.4] & 1.610 \\
\hline Manufacture of Grain Mill Products, Starches and Starch Products [10.6] & 1.610 \\
\hline Manufacture of Other Food Products [10.8] & 1.610 \\
\hline Freight Air Transport and Space Transport [51.2] & 1.611 \\
\hline Passenger Air Transport [51.1] & 1.611 \\
\hline Manufacture of Batteries and Accumulators [27.2] & 1.632 \\
\hline Photographic Activities [74.2] & 1.655 \\
\hline Manufacture of Other Textiles [13.9] & 1.722 \\
\hline Computer Programming, Consultancy and Related Activities [62.0] & 1.756 \\
\hline Camping Grounds, Recreational Vehicle Parks and Trailer Parks [55.3] & 1.759 \\
\hline Other Accommodation [55.9] & 1.759 \\
\hline Holiday and Other Short-Stay Accommodation [55.2] & 1.759 \\
\hline Hotels and Similar Accommodation [55.1] & 1.759 \\
\hline Inland Freight Water Transport [50.4] & 1.764 \\
\hline Inland Passenger Water Transport [50.3] & 1.764 \\
\hline Sea and Coastal Freight Water Transport [50.2] & 1.764 \\
\hline Sea and Coastal Passenger Water Transport [50.1] & 1.764 \\
\hline Manufacture of Railway Locomotives and Rolling Stock [30.2] & 1.768 \\
\hline Manufacture of Other Special-Purpose Machinery [28.9] & 1.769 \\
\hline Manufacture of Agricultural and Forestry Machinery [28.3] & 1.769 \\
\hline Manufacture of Cutlery, Tools and General Hardware [25.7] & 1.769 \\
\hline Manufacture of General-Purpose Machinery [28.1] & 1.769 \\
\hline Manufacture of Metal Forming Machinery and Machine Tools [28.4] & 1.769 \\
\hline Manufacture of Other General-Purpose Machinery [28.2] & 1.769 \\
\hline Cutting, Shaping and Finishing of Stone [23.7] & 1.776 \\
\hline Other Passenger Land Transport [49.3] & 1.790 \\
\hline Manufacture of Air and Spacecraft and Related Machinery [30.3] & 1.848 \\
\hline Tanning and Dressing of Leather; Manufacture of Luggage, Handbags, Saddlery and Harness; Dressing and Dyeing of Fur [15.1] & 1.855 \\
\hline Sale of Motor Vehicle Parts and Accessories [45.3] & 1.889 \\
\hline Wholesale on a Fee Or Contract Basis [46.1] & 1.889 \\
\hline Other Specialized Wholesale [46.7] & 1.889 \\
\hline Sale of Motor Vehicles [45.1] & 1.889 \\
\hline Non-Specialized Wholesale Trade [46.9] & 1.889 \\
\hline Wholesale of Food, Beverages and Tobacco [46.3] & 1.889 \\
\hline Sale, Maintenance and Repair of Motorcycles and Related Parts and Accessories [45.4] & 1.889 \\
\hline Wholesale of Information and Communication Equipment [46.5] & 1.889 \\
\hline Wholesale of Household Goods [46.4] & 1.889 \\
\hline Wholesale of Other Machinery, Equipment and Supplies [46.6] & 1.889 \\
\hline Wholesale of Agricultural Raw Materials and Live Animals [46.2] & 1.889 \\
\hline Other Information Service Activities [63.9] & 1.891 \\
\hline Other Telecommunications Activities [61.9] & 2.001 \\
\hline Radio Broadcasting [60.1] & 2.001 \\
\hline Satellite Telecommunications Activities [61.3] & 2.001 \\
\hline Wired Telecommunications Activities [61.1] & 2.001 \\
\hline Wireless Telecommunications Activities [61.2] & 2.001 \\
\hline Television Programming and Broadcasting Activities [60.2] & 2.001 \\
\hline Renting and Operating of Own Or Leased Real Estate [68.2] & 2.002 \\
\hline Real Estate Activities on a Fee Or Contract Basis [68.3] & 2.002 \\
\hline Buying and Selling of Own Real Estate [68.1] & 2.002 \\
\hline Renting and Leasing of Motor Vehicles [77.1] & 2.009 \\
\hline Manufacture of Clay Building Materials [23.3] & 2.038 \\
\hline Manufacture of Other Porcelain and Ceramic Products [23.4] & 2.038 \\
\hline Manufacture of Electric Lighting Equipment [27.4] & 2.048 \\
\hline Motion Picture, Video and Television Programme Activities [59.1] & 2.143 \\
\hline Legal Activities [69.1] & 2.148 \\
\hline Freight Transport By Road and Removal Services [49.4] & 2.182 \\
\hline Travel Agency and Tour Operator Activities [79.1] & 2.261 \\
\hline Other Reservation Service and Related Activities [79.9] & 2.261 \\
\hline Manufacture of Electric Motors, Generators, Transformers and Electricity Distribution and Control Apparatus [27.1] & 2.261 \\
\hline Technical Testing and Analysis [71.2] & 2.273 \\
\hline Architectural and Engineering Activities and Related Technical Consultancy [71.1] & 2.273 \\
\hline Manufacture of Rubber Products [22.1] & 2.274 \\
\hline Manufacture of Parts and Accessories for Motor Vehicles [29.3] & 2.307 \\
\hline Manufacture of Articles of Concrete, Cement and Plaster [23.6] & 2.330 \\
\hline Security Systems Service Activities [80.2] & 2.409 \\
\hline Private Security Activities [80.1] & 2.409 \\
\hline
\end{tabular}




\section{Upstreamness across NACE industries based on U.S. data [3 of 3]}

\begin{tabular}{|c|c|}
\hline Industry [NACE Code] & Upstreamness \\
\hline Investigation Activities [80.3] & 2.409 \\
\hline Manufacture of Magnetic and Optical Media [26.8] & 2.421 \\
\hline Repair of Personal and Household Goods [95.2] & 2.427 \\
\hline Installation of Industrial Machinery and Equipment [33.2] & 2.427 \\
\hline Repair of Fabricated Metal Products, Machinery and Equipment [33.1] & 2.427 \\
\hline Repair of Computers and Communication Equipment [95.1] & 2.427 \\
\hline Manufacture of Glass and Glass Products [23.1] & 2.435 \\
\hline Combined Facilities Support Activities [81.1] & 2.471 \\
\hline Manufacture of Structural Metal Products [25.1] & 2.486 \\
\hline Manufacture of Steam Generators, Except Central Heating Hot Water Boilers [25.3] & 2.486 \\
\hline Manufacture of Tanks, Reservoirs and Containers of Metal [25.2] & 2.486 \\
\hline Research and Experimental Development on Social Sciences and Humanities [72.2] & 2.490 \\
\hline Research and Experimental Development on Natural Sciences and Engineering [72.1] & 2.490 \\
\hline Manufacture of Refined Petroleum Products [19.2] & 2.529 \\
\hline Manufacture of Coke Oven Products [19.1] & 2.529 \\
\hline Manufacture of Prepared Animal Feeds [10.9] & 2.530 \\
\hline Sawmilling and Planing of Wood [16.1] & 2.532 \\
\hline Manufacture of Products of Wood, Cork, Straw and Plaiting Materials [16.2] & 2.532 \\
\hline Manufacture of Plastics Products [22.2] & 2.581 \\
\hline Postal Activities Under Universal Service Obligation [53.1] & 2.590 \\
\hline Manufacture of Pesticides and Other Agrochemical Products [20.2] & 2.598 \\
\hline Manufacture of Abrasive Products and Non-Metallic Mineral Products N.E.C. [23.9] & 2.599 \\
\hline Manufacture of Wiring and Wiring Devices [27.3] & 2.606 \\
\hline Landscape Service Activities [81.3] & 2.618 \\
\hline Cleaning Activities [81.2] & 2.618 \\
\hline Printing and Service Activities Related to Printing [18.1] & 2.633 \\
\hline Accounting, Bookkeeping and Auditing Activities; Tax Consultancy [69.2] & 2.637 \\
\hline Weaving of Textiles [13.2] & 2.665 \\
\hline Manufacture of Tubes, Pipes, Hollow Profiles and Related Fittings, of Steel [24.2] & 2.677 \\
\hline Manufacture of Other Fabricated Metal Products [25.9] & 2.677 \\
\hline Manufacture of Basic Precious and Other Non-Ferrous Metals [24.4] & 2.677 \\
\hline Manufacturing N.E.C. [32.9] & 2.677 \\
\hline Organization of Conventions and Trade Shows [82.3] & 2.722 \\
\hline Activities of Call Centres [82.2] & 2.722 \\
\hline Office Administrative and Support Activities [82.1] & 2.722 \\
\hline Business Support Service Activities N.E.C. [82.9] & 2.722 \\
\hline Finishing of Textiles [13.3] & 2.737 \\
\hline Preparation and Spinning of Textile Fibres [13.1] & 2.737 \\
\hline Warehousing and Storage [52.1] & 2.755 \\
\hline Specialized Design Activities [74.1] & 2.812 \\
\hline Support Activities for Transportation [52.2] & 2.812 \\
\hline Manufacture of Articles of Paper and Paperboard [17.2] & 2.814 \\
\hline Manufacture of Pulp, Paper and Paperboard [17.1] & 2.814 \\
\hline Passenger Rail Transport, Interurban [49.1] & 2.824 \\
\hline Freight Rail Transport [49.2] & 2.824 \\
\hline Data Processing, Hosting and Related Activities; Web Portals [63.1] & 2.837 \\
\hline Other Human Resources Provision [78.3] & 2.855 \\
\hline Temporary Employment Agency Activities [78.2] & 2.855 \\
\hline Activities of Employment Placement Agencies [78.1] & 2.855 \\
\hline Renting and Leasing of Other Machinery, Equipment and Tangible Goods [77.3] & 2.860 \\
\hline Manufacture of Cement, Lime and Plaster [23.5] & 2.888 \\
\hline Advertising [73.1] & 2.891 \\
\hline Other Professional, Scientific and Technical Activities N.E.C. [74.9] & 2.893 \\
\hline Translation and Interpretation Activities [74.3] & 2.893 \\
\hline Market Research and Public Opinion Polling [73.2] & 2.893 \\
\hline Management Consultancy Activities [70.2] & 2.893 \\
\hline Forging, Pressing, Stamping and Roll-Forming of Metal; Powder Metallurgy [25.5] & 2.935 \\
\hline Activities of Head Offices [70.1] & 2.941 \\
\hline Other Postal and Courier Activities [53.2] & 2.943 \\
\hline Manufacture of Electronic Components and Boards [26.1] & 2.958 \\
\hline Transport Via Pipeline [49.5] & 3.046 \\
\hline Reproduction of Recorded Media [18.2] & 3.068 \\
\hline Treatment and Coating of Metals; Machining [25.6] & 3.074 \\
\hline Manufacture of Man-Made Fibres [20.6] & 3.172 \\
\hline Casting of Metals [24.5] & 3.208 \\
\hline Manufacture of Other Products of First Processing of Steel [24.3] & 3.208 \\
\hline Manufacture of Paints, Varnishes and Similar Coatings, Printing Ink and Mastics [20.3] & 3.254 \\
\hline Manufacture of Basic Chemicals, Fertilizers and Nitrogen Compounds, Plastics and Synthetic Rubber in Primary Forms [20.1] & 3.254 \\
\hline Manufacture of Basic Pharmaceutical Products [21.1] & 3.254 \\
\hline Manufacture of Other Chemical Products [20.5] & 3.254 \\
\hline Leasing of Intellectual Property and Similar Products, Except Copyrighted Works [77.4] & 3.292 \\
\hline Manufacture of Basic Iron and Steel and of Ferro-Alloys [24.1] & 3.347 \\
\hline Manufacture of Refractory Products [23.2] & 3.537 \\
\hline
\end{tabular}




\section{B.3 $\triangle N T C S$}

\section{Table 18: Changes in NTCS by industry (2012-2013 vs. pre-crisis years) [1 of 3]}

\begin{tabular}{|c|c|}
\hline Industry [NACE Code] & $\triangle N T C S$ \\
\hline Development of Building Projects [41.1] & 40.07 \\
\hline Construction of Residential and Non-Residential Buildings [41.2] & 37.69 \\
\hline Construction of Other Civil Engineering Projects [42.9] & 35.92 \\
\hline Data Processing, Hosting and Related Activities; Web Portals [63.1] & 34.80 \\
\hline Construction of Roads and Railways [42.1] & 31.75 \\
\hline Renting and Leasing of Other Machinery, Equipment and Tangible Goods [77.3] & 30.47 \\
\hline Building of Ships and Boats [30.1] & 29.33 \\
\hline Construction of Utility Projects [42.2] & 28.31 \\
\hline Architectural and Engineering Activities and Related Technical Consultancy [71.1] & 27.82 \\
\hline Manufacture of Articles of Concrete, Cement and Plaster [23.6] & 27.71 \\
\hline Electrical, Plumbing and Other Construction Installation Activities [43.2] & 27.46 \\
\hline Buying and Selling of Own Real Estate [68.1] & 26.99 \\
\hline Manufacture of Railway Locomotives and Rolling Stock [30.2] & 26.42 \\
\hline Research and Experimental Development on Natural Sciences and Engineering [72.1] & 26.35 \\
\hline Leasing of Intellectual Property and Similar Products, Except Copyrighted Works [77.4] & 26.07 \\
\hline Demolition and Site Preparation [43.1] & 26.05 \\
\hline Renting and Operating of Own Or Leased Real Estate [68.2] & 25.97 \\
\hline Reproduction of Recorded Media [18.2] & 25.61 \\
\hline Manufacture of Structural Metal Products [25.1] & 24.82 \\
\hline Cutting, Shaping and Finishing of Stone [23.7] & 24.55 \\
\hline Other Professional, Scientific and Technical Activities N.E.C. [74.9] & 23.48 \\
\hline Renting and Leasing of Motor Vehicles [77.1] & 23.14 \\
\hline Other Specialized Construction Activities [43.9] & 22.74 \\
\hline Building Completion and Finishing [43.3] & 22.57 \\
\hline Landscape Service Activities [81.3] & 22.20 \\
\hline Manufacture of Coke Oven Products [19.1] & 22.00 \\
\hline Legal Activities [69.1] & 21.80 \\
\hline Private Security Activities [80.1] & 21.75 \\
\hline Combined Facilities Support Activities [81.1] & 21.75 \\
\hline Cleaning Activities [81.2] & 21.70 \\
\hline Manufacture of Products of Wood, Cork, Straw and Plaiting Materials [16.2] & 21.68 \\
\hline Business Support Service Activities N.E.C. [82.9] & 20.61 \\
\hline Manufacture of Paints, Varnishes and Similar Coatings, Printing Ink and Mastics [20.3] & 20.36 \\
\hline Other Telecommunications Activities [61.9] & 20.31 \\
\hline Real Estate Activities on a Fee Or Contract Basis [68.3] & 19.80 \\
\hline Manufacture of Glass and Glass Products [23.1] & 19.64 \\
\hline Other Accommodation [55.9] & 19.51 \\
\hline Management Consultancy Activities [70.2] & 19.49 \\
\hline Activities of Call Centres [82.2] & 19.30 \\
\hline Manufacture of Communication Equipment [26.3] & 19.29 \\
\hline Other Human Resources Provision [78.3] & 18.91 \\
\hline Sea and Coastal Freight Water Transport [50.2] & 18.74 \\
\hline Wired Telecommunications Activities [61.1] & 18.70 \\
\hline Manufacture of Bodies (Coachwork) for Motor Vehicles; Manufacture of Trailers and Semi-Trailers [29.2] & 18.69 \\
\hline Renting and Leasing of Personal and Household Goods [77.2] & 18.62 \\
\hline Transport Via Pipeline [49.5] & 18.57 \\
\hline Office Administrative and Support Activities [82.1] & 18.39 \\
\hline Sound Recording and Music Publishing Activities [59.2] & 18.23 \\
\hline Satellite Telecommunications Activities [61.3] & 18.03 \\
\hline Inland Passenger Water Transport [50.3] & 17.99 \\
\hline Manufacture of Tanks, Reservoirs and Containers of Metal [25.2] & 17.97 \\
\hline Accounting, Bookkeeping and Auditing Activities; Tax Consultancy [69.2] & 17.82 \\
\hline Sea and Coastal Passenger Water Transport [50.1] & 17.66 \\
\hline Manufacture of Electric Motors, Generators, Transformers and Electricity Distribution and Control Apparatus [27.1] & 17.27 \\
\hline
\end{tabular}




\section{Changes in NTCS by industry (2012-2013 vs. pre-crisis years) [2 of 3]}

\begin{tabular}{|c|c|}
\hline Industry [NACE Code] & $\triangle N T C S$ \\
\hline Security Systems Service Activities [80.2] & 17.18 \\
\hline Repair of Personal and Household Goods [95.2] & 17.16 \\
\hline Market Research and Public Opinion Polling [73.2] & 17.15 \\
\hline Radio Broadcasting [60.1] & 17.11 \\
\hline Manufacture of Furniture [31.0] & 17.03 \\
\hline Wireless Telecommunications Activities [61.2] & 16.99 \\
\hline Manufacture of Games and Toys [32.4] & 16.84 \\
\hline Repair of Computers and Communication Equipment [95.1] & 16.64 \\
\hline Technical Testing and Analysis [71.2] & 16.61 \\
\hline Passenger Air Transport [51.1] & 16.59 \\
\hline Wholesale of Other Machinery, Equipment and Supplies [46.6] & 16.58 \\
\hline Other Specialized Wholesale [46.7] & 16.14 \\
\hline Retail Sale of Other Household Equipment in Specialized Stores [47.5] & 16.06 \\
\hline Other Passenger Land Transport [49.3] & 15.98 \\
\hline Repair of Fabricated Metal Products, Machinery and Equipment [33.1] & 15.85 \\
\hline Retail Sale of Information and Communication Equipment in Specialized Stores [47.4] & 15.80 \\
\hline Advertising [73.1] & 15.77 \\
\hline Installation of Industrial Machinery and Equipment [33.2] & 15.61 \\
\hline Manufacture of Cement, Lime and Plaster [23.5] & 15.51 \\
\hline Printing and Service Activities Related to Printing [18.1] & 15.46 \\
\hline Computer Programming, Consultancy and Related Activities [62.0] & 15.38 \\
\hline Manufacture of Agricultural and Forestry Machinery [28.3] & 15.37 \\
\hline Postal Activities Under Universal Service Obligation [53.1] & 15.30 \\
\hline Manufacture of Tubes, Pipes, Hollow Profiles and Related Fittings, of Steel [24.2] & 15.30 \\
\hline Manufacture of Abrasive Products and Non-Metallic Mineral Products N.E.C. [23.9] & 15.21 \\
\hline Travel Agency and Tour Operator Activities [79.1] & 15.11 \\
\hline Sale of Motor Vehicle Parts and Accessories [45.3] & 15.11 \\
\hline Translation and Interpretation Activities [74.3] & 15.09 \\
\hline Research and Experimental Development on Social Sciences and Humanities [72.2] & 15.01 \\
\hline Publishing of Books, Periodicals and Other Publishing Activities [58.1] & 15.00 \\
\hline Motion Picture, Video and Television Programme Activities [59.1] & 14.97 \\
\hline Other Information Service Activities [63.9] & 14.96 \\
\hline Wholesale on a Fee Or Contract Basis [46.1] & 14.92 \\
\hline Wholesale of Information and Communication Equipment [46.5] & 14.82 \\
\hline Camping Grounds, Recreational Vehicle Parks and Trailer Parks [55.3] & 14.63 \\
\hline Maintenance and Repair of Motor Vehicles [45.2] & 14.62 \\
\hline Manufacture of Pesticides and Other Agrochemical Products [20.2] & 14.47 \\
\hline Temporary Employment Agency Activities [78.2] & 14.37 \\
\hline Sale of Motor Vehicles [45.1] & 14.37 \\
\hline Sawmilling and Planing of Wood [16.1] & 14.36 \\
\hline Manufacture of Sports Goods [32.3] & 14.33 \\
\hline Activities of Head Offices [70.1] & 14.19 \\
\hline Manufacture of Motor Vehicles [29.1] & 14.07 \\
\hline Photographic Activities [74.2] & 14.06 \\
\hline Manufacture of Other Fabricated Metal Products [25.9] & 13.86 \\
\hline Event Catering and Other Food Service Activities [56.2] & 13.85 \\
\hline Manufacture of Wearing Apparel, Except Fur Apparel [14.1] & 13.80 \\
\hline Non-Specialized Wholesale Trade [46.9] & 13.73 \\
\hline Other Postal and Courier Activities [53.2] & 13.67 \\
\hline Other Reservation Service and Related Activities [79.9] & 13.61 \\
\hline Manufacture of Other Textiles [13.9] & 13.45 \\
\hline Manufacture of Other General-Purpose Machinery [28.2] & 13.29 \\
\hline Inland Freight Water Transport [50.4] & 13.28 \\
\hline Manufacture of Magnetic and Optical Media [26.8] & 13.23 \\
\hline Specialized Design Activities [74.1] & 13.12 \\
\hline Software Publishing [58.2] & 12.94 \\
\hline Processing and Preserving of Fish, Crustaceans and Molluscs [10.2] & 12.89 \\
\hline Wholesale of Household Goods [46.4] & 12.55 \\
\hline Manufacture of Computers and Peripheral Equipment [26.2] & 12.42 \\
\hline Manufacture of Other Special-Purpose Machinery [28.9] & 12.14 \\
\hline Retail Sale Via Stalls and Markets [47.8] & 12.11 \\
\hline Retail Sale of Cultural and Recreation Goods in Specialized Stores [47.6] & 12.07 \\
\hline Manufacture of Other Porcelain and Ceramic Products [23.4] & 12.02 \\
\hline Investigation Activities [80.3] & 12.01 \\
\hline Retail Sale of Other Goods in Specialized Stores [47.7] & 11.80 \\
\hline Manufacture of Knitted and Crocheted Apparel [14.3] & 11.72 \\
\hline Freight Transport By Road and Removal Services [49.4] & 11.71 \\
\hline Manufacture of Soap and Detergents, Cleaning and Polishing Preparations, Perfumes and Toilet Preparations [20.4] & 11.68 \\
\hline Wholesale of Agricultural Raw Materials and Live Animals [46.2] & 11.62 \\
\hline Holiday and Other Short-Stay Accommodation [55.2] & 11.53 \\
\hline Manufacture of Other Food Products [10.8] & 11.44 \\
\hline Retail Trade Not in Stores, Stalls Or Markets [47.9] & 11.35 \\
\hline
\end{tabular}




\section{Changes in NTCS by industry (2012-2013 vs. pre-crisis years) [3 of 3]}

\begin{tabular}{|c|c|}
\hline Industry [NACE Code] & $\triangle N T C S$ \\
\hline Veterinary Activities [75.0] & 11.10 \\
\hline Manufacture of Air and Spacecraft and Related Machinery [30.3] & 11.08 \\
\hline Manufacture of Consumer Electronics [26.4] & 10.92 \\
\hline Manufacturing N.E.C. [32.9] & 10.90 \\
\hline Manufacture of General-Purpose Machinery [28.1] & 10.75 \\
\hline Manufacture of Medical and Dental Instruments and Supplies [32.5] & 10.34 \\
\hline Manufacture of Steam Generators, Except Central Heating Hot Water Boilers [25.3] & 10.26 \\
\hline Manufacture of Jewellery, Bijouterie and Related Articles [32.1] & 10.21 \\
\hline Television Programming and Broadcasting Activities [60.2] & 10.03 \\
\hline Finishing of Textiles [13.3] & 10.03 \\
\hline Manufacture of Beverages [11.0] & 9.75 \\
\hline Wholesale of Food, Beverages and Tobacco [46.3] & 9.75 \\
\hline Support Activities for Transportation [52.2] & 9.71 \\
\hline Manufacture of Plastics Products [22.2] & 9.59 \\
\hline Manufacture of Musical Instruments [32.2] & 9.50 \\
\hline Freight Rail Transport [49.2] & 9.49 \\
\hline Manufacture of Electronic Components and Boards [26.1] & 9.37 \\
\hline Manufacture of Cutlery, Tools and General Hardware [25.7] & 9.19 \\
\hline Forging, Pressing, Stamping and Roll-Forming of Metal; Powder Metallurgy [25.5] & 9.18 \\
\hline Manufacture of Other Electrical Equipment [27.9] & 8.97 \\
\hline Passenger Rail Transport, Interurban [49.1] & 8.77 \\
\hline Manufacture of Irradiation, Electromedical and Electrotherapeutic Equipment [26.6] & 8.74 \\
\hline Sale, Maintenance and Repair of Motorcycles and Related Parts and Accessories [45.4] & 8.71 \\
\hline Manufacture of Prepared Animal Feeds [10.9] & 8.70 \\
\hline Freight Air Transport and Space Transport [51.2] & 8.64 \\
\hline Manufacture of Instruments and Appliances for Measuring, Testing and Navigation; Watches and Clocks [26.5] & 8.56 \\
\hline Manufacture of Other Chemical Products [20.5] & 8.53 \\
\hline Manufacture of Clay Building Materials [23.3] & 8.53 \\
\hline Retail Sale in Non-Specialized Stores [47.1] & 8.53 \\
\hline Manufacture of Refractory Products [23.2] & 8.42 \\
\hline Manufacture of Basic Iron and Steel and of Ferro-Alloys [24.1] & 8.33 \\
\hline Manufacture of Bakery and Farinaceous Products [10.7] & 8.07 \\
\hline Retail Sale of Automotive Fuel in Specialized Stores [47.3] & 7.82 \\
\hline Retail Sale of Food, Beverages and Tobacco in Specialized Stores [47.2] & 7.80 \\
\hline Treatment and Coating of Metals; Machining [25.6] & 7.76 \\
\hline Manufacture of Articles of Fur [14.2] & 7.65 \\
\hline Manufacture of Footwear [15.2] & 7.49 \\
\hline Casting of Metals [24.5] & 7.33 \\
\hline Manufacture of Parts and Accessories for Motor Vehicles [29.3] & 7.29 \\
\hline Warehousing and Storage [52.1] & 6.99 \\
\hline Manufacture of Wiring and Wiring Devices [27.3] & 6.85 \\
\hline Manufacture of Metal Forming Machinery and Machine Tools [28.4] & 6.76 \\
\hline Manufacture of Basic Pharmaceutical Products [21.1] & 6.54 \\
\hline Restaurants and Mobile Food Service Activities [56.1] & 6.54 \\
\hline Organization of Conventions and Trade Shows [82.3] & 6.45 \\
\hline Processing and Preserving of Meat and Production of Meat Products [10.1] & 6.16 \\
\hline Manufacture of Articles of Paper and Paperboard [17.2] & 5.92 \\
\hline Manufacture of Basic Precious and Other Non-Ferrous Metals [24.4] & 5.90 \\
\hline Hotels and Similar Accommodation [55.1] & 5.65 \\
\hline Manufacture of Rubber Products [22.1] & 5.25 \\
\hline Processing and Preserving of Fruit and Vegetables [10.3] & 5.24 \\
\hline Preparation and Spinning of Textile Fibres [13.1] & 5.05 \\
\hline Manufacture of Electric Lighting Equipment [27.4] & 5.00 \\
\hline Manufacture of Basic Chemicals, Fertilizers and Nitrogen Compounds, Plastics and Synthetic Rubber in Primary Forms [20.1] & 4.85 \\
\hline Manufacture of Refined Petroleum Products [19.2] & 4.68 \\
\hline Manufacture of Dairy Products [10.5] & 4.48 \\
\hline Manufacture of Pharmaceutical Preparations [21.2] & 4.47 \\
\hline Manufacture of Vegetable and Animal Oils and Fats [10.4] & 4.46 \\
\hline Activities of Employment Placement Agencies [78.1] & 3.52 \\
\hline Manufacture of Transport Equipment N.E.C. [30.9] & 3.49 \\
\hline Manufacture of Pulp, Paper and Paperboard [17.1] & 3.43 \\
\hline Manufacture of Domestic Appliances [27.5] & 3.26 \\
\hline Manufacture of Other Products of First Processing of Steel [24.3] & 2.82 \\
\hline Tanning and Dressing of Leather; Manufacture of Luggage, Handbags, Saddlery and Harness; Dressing and Dyeing of Fur [15.1] & 1.44 \\
\hline Manufacture of Optical Instruments and Photographic Equipment [26.7] & 1.23 \\
\hline Manufacture of Weapons and Ammunition [25.4] & -0.63 \\
\hline Manufacture of Grain Mill Products, Starches and Starch Products [10.6] & -0.67 \\
\hline Weaving of Textiles [13.2] & -1.30 \\
\hline Beverage Serving Activities [56.3] & -5.49 \\
\hline Manufacture of Batteries and Accumulators [27.2] & -7.50 \\
\hline Manufacture of Man-Made Fibres [20.6] & -11.42 \\
\hline Manufacture of Tobacco Products [12.0] & -19.82 \\
\hline
\end{tabular}




\section{B.4 RelativeSize}

Table 19: RelativeSize of NACE industries based on EU data [1 of 3]

\begin{tabular}{|c|c|}
\hline Industry [NACE Code] & RelativeSize \\
\hline Treatment and Coating of Metals; Machining [25.6] & -0.382 \\
\hline Reproduction of Recorded Media [18.2] & -0.344 \\
\hline Manufacture of Magnetic and Optical Media [26.8] & -0.291 \\
\hline Specialized Design Activities [74.1] & -0.246 \\
\hline Cutting, Shaping and Finishing of Stone [23.7] & -0.231 \\
\hline Finishing of Textiles [13.3] & -0.222 \\
\hline Manufacture of Structural Metal Products [25.1] & -0.221 \\
\hline Manufacture of Other Products of First Processing of Steel [24.3] & -0.208 \\
\hline Translation and Interpretation Activities [74.3] & -0.190 \\
\hline Other Professional, Scientific and Technical Activities N.E.C. [74.9] & -0.190 \\
\hline Building Completion and Finishing [43.3] & -0.188 \\
\hline Printing and Service Activities Related to Printing [18.1] & -0.186 \\
\hline Veterinary Activities $[75.0]$ & -0.176 \\
\hline Forging, Pressing, Stamping and Roll-Forming of Metal; Powder Metallurgy [25.5] & -0.175 \\
\hline Manufacture of Musical Instruments [32.2] & -0.168 \\
\hline Transport Via Pipeline [49.5] & -0.167 \\
\hline Development of Building Projects [41.1] & -0.145 \\
\hline Manufacturing N.E.C. [32.9] & -0.142 \\
\hline Manufacture of Jewellery, Bijouterie and Related Articles [32.1] & -0.139 \\
\hline Manufacture of Articles of Fur [14.2] & -0.136 \\
\hline Other Specialized Construction Activities [43.9] & -0.129 \\
\hline Preparation and Spinning of Textile Fibres [13.1] & -0.125 \\
\hline Repair of Computers and Communication Equipment [95.1] & -0.107 \\
\hline Repair of Personal and Household Goods [95.2] & -0.107 \\
\hline Demolition and Site Preparation [43.1] & -0.096 \\
\hline Manufacture of Plastics Products [22.2] & -0.093 \\
\hline Manufacture of Other Fabricated Metal Products [25.9] & -0.092 \\
\hline Advertising [73.1] & -0.086 \\
\hline Leasing of Intellectual Property and Similar Products, Except Copyrighted Works [77.4] & -0.082 \\
\hline Manufacture of Refractory Products [23.2] & -0.074 \\
\hline Photographic Activities [74.2] & -0.073 \\
\hline Activities of Head Offices [70.1] & -0.071 \\
\hline Market Research and Public Opinion Polling [73.2] & -0.064 \\
\hline Tanning and Dressing of Leather; Manufacture of Luggage, Handbags, Saddlery and Harness; Dressing and Dyeing of Fur [15.1] & -0.053 \\
\hline Renting and Leasing of Other Machinery, Equipment and Tangible Goods [77.3] & -0.052 \\
\hline Office Administrative and Support Activities [82.1] & -0.047 \\
\hline Activities of Call Centres [82.2] & -0.047 \\
\hline Organization of Conventions and Trade Shows [82.3] & -0.047 \\
\hline Business Support Service Activities N.E.C. [82.9] & -0.047 \\
\hline Electrical, Plumbing and Other Construction Installation Activities [43.2] & -0.039 \\
\hline Buying and Selling of Own Real Estate [68.1] & -0.037 \\
\hline Renting and Operating of Own Or Leased Real Estate [68.2] & -0.037 \\
\hline Real Estate Activities on a Fee Or Contract Basis [68.3] & -0.037 \\
\hline Freight Transport By Road and Removal Services [49.4] & -0.036 \\
\hline Motion Picture, Video and Television Programme Activities [59.1] & -0.032 \\
\hline Accounting, Bookkeeping and Auditing Activities; Tax Consultancy [69.2] & -0.029 \\
\hline Passenger Rail Transport, Interurban [49.1] & -0.024 \\
\hline Freight Rail Transport [49.2] & -0.024 \\
\hline Manufacture of Other Textiles [13.9] & -0.013 \\
\hline Casting of Metals [24.5] & -0.013 \\
\hline Support Activities for Transportation [52.2] & -0.011 \\
\hline Sale of Motor Vehicles [45.1] & -0.006 \\
\hline Sale of Motor Vehicle Parts and Accessories [45.3] & -0.006 \\
\hline Sale, Maintenance and Repair of Motorcycles and Related Parts and Accessories [45.4] & -0.006 \\
\hline
\end{tabular}




\section{RelativeSize of NACE industries based on EU data [2 of 3]}

\begin{tabular}{|c|c|}
\hline Industry [NACE Code] & RelativeSize \\
\hline Maintenance and Repair of Motor Vehicles [45.2] & -0.004 \\
\hline Restaurants and Mobile Food Service Activities [56.1] & -0.001 \\
\hline Event Catering and Other Food Service Activities [56.2] & -0.001 \\
\hline Beverage Serving Activities [56.3] & -0.001 \\
\hline Management Consultancy Activities [70.2] & 0.011 \\
\hline Manufacture of Man-Made Fibres [20.6] & 0.011 \\
\hline Legal Activities [69.1] & 0.019 \\
\hline Sawmilling and Planing of Wood [16.1] & 0.025 \\
\hline Manufacture of Other Chemical Products [20.5] & 0.028 \\
\hline Wholesale on a Fee Or Contract Basis [46.1] & 0.037 \\
\hline Wholesale of Agricultural Raw Materials and Live Animals [46.2] & 0.037 \\
\hline Wholesale of Food, Beverages and Tobacco [46.3] & 0.037 \\
\hline Wholesale of Household Goods [46.4] & 0.037 \\
\hline Wholesale of Information and Communication Equipment [46.5] & 0.037 \\
\hline Wholesale of Other Machinery, Equipment and Supplies [46.6] & 0.037 \\
\hline Other Specialized Wholesale [46.7] & 0.037 \\
\hline Non-Specialized Wholesale Trade [46.9] & 0.037 \\
\hline Manufacture of Articles of Concrete, Cement and Plaster [23.6] & 0.041 \\
\hline Manufacture of Abrasive Products and Non-Metallic Mineral Products N.E.C. [23.9] & 0.041 \\
\hline Hotels and Similar Accommodation [55.1] & 0.046 \\
\hline Holiday and Other Short-Stay Accommodation [55.2] & 0.046 \\
\hline Camping Grounds, Recreational Vehicle Parks and Trailer Parks [55.3] & 0.046 \\
\hline Other Accommodation [55.9] & 0.046 \\
\hline Architectural and Engineering Activities and Related Technical Consultancy [71.1] & 0.049 \\
\hline Technical Testing and Analysis [71.2] & 0.049 \\
\hline Installation of Industrial Machinery and Equipment [33.2] & 0.056 \\
\hline Manufacture of Sports Goods [32.3] & 0.057 \\
\hline Renting and Leasing of Motor Vehicles [77.1] & 0.066 \\
\hline Cleaning Activities [81.2] & 0.067 \\
\hline Landscape Service Activities [81.3] & 0.067 \\
\hline Warehousing and Storage [52.1] & 0.072 \\
\hline Data Processing, Hosting and Related Activities; Web Portals [63.1] & 0.074 \\
\hline Manufacture of Footwear [15.2] & 0.076 \\
\hline Repair of Fabricated Metal Products, Machinery and Equipment [33.1] & 0.081 \\
\hline Manufacture of Paints, Varnishes and Similar Coatings, Printing Ink and Mastics [20.3] & 0.081 \\
\hline Renting and Leasing of Personal and Household Goods [77.2] & 0.081 \\
\hline Manufacture of Bodies (Coachwork) for Motor Vehicles; Manufacture of Trailers and Semi-Trailers [29.2] & 0.081 \\
\hline Other Passenger Land Transport [49.3] & 0.087 \\
\hline Construction of Residential and Non-Residential Buildings [41.2] & 0.088 \\
\hline Manufacture of Cutlery, Tools and General Hardware [25.7] & 0.094 \\
\hline Manufacture of Furniture [31.0] & 0.099 \\
\hline Weaving of Textiles [13.2] & 0.100 \\
\hline Sound Recording and Music Publishing Activities [59.2] & 0.102 \\
\hline Manufacture of Products of Wood, Cork, Straw and Plaiting Materials [16.2] & 0.112 \\
\hline Manufacture of Tanks, Reservoirs and Containers of Metal [25.2] & 0.116 \\
\hline Sea and Coastal Passenger Water Transport [50.1] & 0.126 \\
\hline Sea and Coastal Freight Water Transport [50.2] & 0.126 \\
\hline Inland Passenger Water Transport [50.3] & 0.126 \\
\hline Inland Freight Water Transport [50.4] & 0.126 \\
\hline Other Information Service Activities [63.9] & 0.144 \\
\hline Construction of Other Civil Engineering Projects [42.9] & 0.148 \\
\hline Manufacture of Articles of Paper and Paperboard [17.2] & 0.155 \\
\hline Manufacture of Other Electrical Equipment [27.9] & 0.163 \\
\hline Combined Facilities Support Activities [81.1] & 0.169 \\
\hline Manufacture of Wearing Apparel, Except Fur Apparel [14.1] & 0.173 \\
\hline Manufacture of Metal Forming Machinery and Machine Tools [28.4] & 0.177 \\
\hline Manufacture of Other General-Purpose Machinery [28.2] & 0.177 \\
\hline Manufacture of Electronic Components and Boards [26.1] & 0.182 \\
\hline Construction of Utility Projects [42.2] & 0.186 \\
\hline Travel Agency and Tour Operator Activities [79.1] & 0.187 \\
\hline Other Reservation Service and Related Activities [79.9] & 0.187 \\
\hline Manufacture of Transport Equipment N.E.C. [30.9] & 0.190 \\
\hline Manufacture of Parts and Accessories for Motor Vehicles [29.3] & 0.207 \\
\hline Manufacture of Irradiation, Electromedical and Electrotherapeutic Equipment [26.6] & 0.208 \\
\hline Manufacture of Steam Generators, Except Central Heating Hot Water Boilers [25.3] & 0.209 \\
\hline Manufacture of Clay Building Materials [23.3] & 0.216 \\
\hline Manufacture of Other Special-Purpose Machinery [28.9] & 0.217 \\
\hline Manufacture of Prepared Animal Feeds [10.9] & 0.217 \\
\hline Computer Programming, Consultancy and Related Activities [62.0] & 0.225 \\
\hline Manufacture of Glass and Glass Products [23.1] & 0.227 \\
\hline Software Publishing [58.2] & 0.230 \\
\hline Manufacture of Knitted and Crocheted Apparel [14.3] & 0.230 \\
\hline
\end{tabular}




\section{RelativeSize of NACE industries based on EU data [3 of 3]}

\begin{tabular}{|c|c|}
\hline Industry [NACE Code] & RelativeSize \\
\hline Manufacture of Basic Precious and Other Non-Ferrous Metals [24.4] & 0.232 \\
\hline Manufacture of Coke Oven Products [19.1] & 0.241 \\
\hline Manufacture of Wiring and Wiring Devices [27.3] & 0.242 \\
\hline Processing and Preserving of Fish, Crustaceans and Molluscs [10.2] & 0.242 \\
\hline Publishing of Books, Periodicals and Other Publishing Activities [58.1] & 0.244 \\
\hline Manufacture of Basic Pharmaceutical Products [21.1] & 0.245 \\
\hline Manufacture of Electric Lighting Equipment [27.4] & 0.249 \\
\hline Manufacture of Bakery and Farinaceous Products [10.7] & 0.251 \\
\hline Research and Experimental Development on Natural Sciences and Engineering [72.1] & 0.274 \\
\hline Research and Experimental Development on Social Sciences and Humanities [72.2] & 0.274 \\
\hline Construction of Roads and Railways [42.1] & 0.275 \\
\hline Manufacture of Other Porcelain and Ceramic Products [23.4] & 0.279 \\
\hline Private Security Activities [80.1] & 0.281 \\
\hline Security Systems Service Activities [80.2] & 0.281 \\
\hline Investigation Activities [80.3] & 0.281 \\
\hline Activities of Employment Placement Agencies [78.1] & 0.288 \\
\hline Temporary Employment Agency Activities [78.2] & 0.288 \\
\hline Other Human Resources Provision [78.3] & 0.288 \\
\hline Manufacture of Beverages [11.0] & 0.293 \\
\hline Manufacture of Pesticides and Other Agrochemical Products [20.2] & 0.300 \\
\hline Manufacture of Grain Mill Products, Starches and Starch Products [10.6] & 0.303 \\
\hline Manufacture of Tubes, Pipes, Hollow Profiles and Related Fittings, of Steel [24.2] & 0.310 \\
\hline Manufacture of Basic Chemicals, Fertilizers and Nitrogen Compounds, Plastics and Synthetic Rubber in Primary Forms [20.1] & 0.313 \\
\hline Retail Sale in Non-Specialized Stores [47.1] & 0.317 \\
\hline Retail Sale of Food, Beverages and Tobacco in Specialized Stores [47.2] & 0.317 \\
\hline Retail Sale of Automotive Fuel in Specialized Stores [47.3] & 0.317 \\
\hline Retail Sale of Information and Communication Equipment in Specialized Stores [47.4] & 0.317 \\
\hline Retail Sale of Other Household Equipment in Specialized Stores [47.5] & 0.317 \\
\hline Retail Sale of Cultural and Recreation Goods in Specialized Stores [47.6] & 0.317 \\
\hline Retail Sale of Other Goods in Specialized Stores [47.7] & 0.317 \\
\hline Retail Sale Via Stalls and Markets [47.8] & 0.317 \\
\hline Retail Trade Not in Stores, Stalls Or Markets [47.9] & 0.317 \\
\hline Manufacture of Medical and Dental Instruments and Supplies [32.5] & 0.327 \\
\hline Processing and Preserving of Fruit and Vegetables [10.3] & 0.338 \\
\hline Manufacture of Instruments and Appliances for Measuring, Testing and Navigation; Watches and Clocks [26.5] & 0.345 \\
\hline Manufacture of Electric Motors, Generators, Transformers and Electricity Distribution and Control Apparatus [27.1] & 0.357 \\
\hline Manufacture of Agricultural and Forestry Machinery [28.3] & 0.359 \\
\hline Manufacture of Cement, Lime and Plaster [23.5] & 0.366 \\
\hline Processing and Preserving of Meat and Production of Meat Products [10.1] & 0.366 \\
\hline Manufacture of Soap and Detergents, Cleaning and Polishing Preparations, Perfumes and Toilet Preparations [20.4] & 0.380 \\
\hline Manufacture of Vegetable and Animal Oils and Fats [10.4] & 0.388 \\
\hline Manufacture of Optical Instruments and Photographic Equipment [26.7] & 0.397 \\
\hline Manufacture of Games and Toys [32.4] & 0.403 \\
\hline Manufacture of Computers and Peripheral Equipment [26.2] & 0.406 \\
\hline Manufacture of Batteries and Accumulators [27.2] & 0.411 \\
\hline Manufacture of Rubber Products [22.1] & 0.414 \\
\hline Manufacture of General-Purpose Machinery [28.1] & 0.433 \\
\hline Manufacture of Pulp, Paper and Paperboard [17.1] & 0.433 \\
\hline Other Postal and Courier Activities [53.2] & 0.442 \\
\hline Manufacture of Basic Iron and Steel and of Ferro-Alloys [24.1] & 0.443 \\
\hline Manufacture of Communication Equipment [26.3] & 0.457 \\
\hline Manufacture of Dairy Products [10.5] & 0.467 \\
\hline Building of Ships and Boats [30.1] & 0.478 \\
\hline Manufacture of Other Food Products [10.8] & 0.482 \\
\hline Manufacture of Refined Petroleum Products [19.2] & 0.494 \\
\hline Postal Activities Under Universal Service Obligation [53.1] & 0.538 \\
\hline Manufacture of Domestic Appliances [27.5] & 0.541 \\
\hline Passenger Air Transport [51.1] & 0.566 \\
\hline Freight Air Transport and Space Transport [51.2] & 0.566 \\
\hline Manufacture of Weapons and Ammunition [25.4] & 0.573 \\
\hline Manufacture of Railway Locomotives and Rolling Stock [30.2] & 0.591 \\
\hline Radio Broadcasting [60.1] & 0.598 \\
\hline Television Programming and Broadcasting Activities [60.2] & 0.598 \\
\hline Manufacture of Consumer Electronics [26.4] & 0.630 \\
\hline Wired Telecommunications Activities [61.1] & 0.635 \\
\hline Wireless Telecommunications Activities [61.2] & 0.635 \\
\hline Satellite Telecommunications Activities [61.3] & 0.635 \\
\hline Other Telecommunications Activities [61.9] & 0.635 \\
\hline Manufacture of Motor Vehicles [29.1] & 0.677 \\
\hline Manufacture of Pharmaceutical Preparations [21.2] & 0.701 \\
\hline Manufacture of Air and Spacecraft and Related Machinery [30.3] & 0.713 \\
\hline Manufacture of Tobacco Products [12.0] & 0.791 \\
\hline
\end{tabular}

